\title{
Türk Lirası Reel Kuru Denge Değerinde Mi?
}

\author{
Is Turkish Lira Real Exchange Rate in Equilibrium?
}

\author{
Güzin BAYAR', Selman TOKPUNAR²
}

\begin{abstract}
ÖZET
Reel kur çok sayıda makroekonomik değişkeni etkileyen önemli bir göstergedir. Bu çalışmada Türk Lirası reel kurunun uzun dönemli denge değeri ve bu denge değerinden ne kadar uzakta olduğu ekonometrik olarak incelenmiştir. Tamamen Değiştirilmiş En Küçük Kareler Yöntemi (FMOLS) kullanılarak oluşturulan uzun vadeli modelde, reel kur bağımlı değişken olarak ve "Türkiye ve OECD Ülkelerinin Göreli Birim Iş̧ Gücü Maliyetleri", "Türkiye'ye Yurt Dışından Sermaye Akımları", "Türkiye'nin GSYH'sı", "Dış Ticaret Hacmi/GSYH Oranı" bağımsız değişkenler olarak alınmıştır. Regresyon analizinin sonuçları, Balassa-Samuelson etkisini doğrulamaktadır; Türkiye'nin büyüme oranının artması reel kura değerlenme yönünde etki etmektedir. Dış Ticaret Hacminde meydana gelen artış TL'yi değer kazandırma yönünde etkilemektedir. Türkiye'ye yurt dışından sermaye girişlerinin TL'de değerlenme baskısı yarattığı görülmektedir. OECD ülkelerinin Türkiye'ye göreli olarak iş gücü maliyetlerinin artışı reel kura değer kaybettirmekte, söz konusu ülkelerin rekabet gücünün azalmasına, Türkiye'nin rekabet gücünün ise artışına yol açmaktadır. Analiz sonuçları, son dönemde TL reel kurunun denge değerine yakın seviyelerde olduğunu göstermektedir. Makale, kurun denge değerine politika müdahalesi yapılıp yapılmaması konusunu da tartışmaya açmaktadır.
\end{abstract}

Anahtar Kelimeler: FMOLS, reel kur, denge,

balassa-samuelson etkisi

\section{GíRiş}

Ticaret yapan ülkelerin ürünlerinin göreli fiyatlarının, fiyat rekabetindeki güçlerinin bir göstergesi olan reel kur makroekonomik dengeler açısından önemli bir değişkendir. Reel kurdaki değişimler, dış ticaret başta olmak üzere çeşitli diğer makroekonomik değişkenleri etkilemektedir. Reel kurun dengede olmaması ekonomideki diğer dengeleri de bozucu etkilere yol açmaktadır.

Bu noktada reel kurun "denge değeri"nin ne olduğunun tanımlanması önemlidir. Reel kurun denge değeri belirlenirken, yalnızca döviz piyasasını dengeye getiren değil, ekonominin iç ve dış dengelerini (en azından mal, hizmet ve döviz piyasalarında dengeyi) eşanlı olarak sağlayan kur anlaşılmalıdır(Edwards (2001), Fischer (2001), Kibritçioğlu ve Kibritçioğlu (2004)). Reel kurun uzun dönemli denge değerinden pozitif yönde sapması ülkenin reel kurunun aşırı de-

\section{ABSTRACT}

Real exchange rate is an important variable affecting many macroeconomic indicators. In this study, long run equilibrium value of Turkish Lira is estimated and how far away is TL real exchange rate from its equilibrium value is examined. Long run cointegration relationship is estimated using fully modified ordinary least squares. Dependent variable is real exchange rate of TL and independent variables are "relative unit labor costs of OECD countries and Turkey", "foreing capital inflows to Turkey", "GDP of Turkey", "foreign trade volume/GDP ratio". Regression results approve Balassa-Samuelson effect for Turkey, increase in GDP of Turkey affects TL real exchange rate in the appreciation direction. Rise in foreign trade volume appreciates TL. Increasing capital inflows, puts appreciation pressure on TL. An increase in relative unit labor costs of OECD countries in comparison to Turkey's, by decreasing competitive power of OECD countries, causes depreciation in TL. Results of the analysis show that, TL real exchange rate is close to its equilibrium value in the last period. Article also aim to open a discussion about whether it is advisable to do policy intervention to the equilibrium value of real exchange rate.

Keywords: FMOLS, real exchage rate, equilibrium, balassa-samuelson effect

ğerlenmesi, negatif yönde sapması ise reel kurunun aşırı değer kaybı olarak adlandırılmaktadır.

Bu çalışmada TL reel kurunun denge değeri hesaplanmaktadır. Hesaplamalarda Türkiye Cumhuriyet Merkez Bankasının (TCMB) reel kur tanımı ve verileri kullanılmıştır. Türkiye Cumhuriyet Merkez Bankası, TL reel kurunu hesaplarken, nominal kuru, dış ticaret yaptığımız ülkelerin payları ile ağırlıklandırıımış fiyat seviyesi farklarından geometrik ortalama yöntemiyle arındırmaktadır. Hesaplama denklemi aşağıdaki gibi ifade edilmektedir (Saygılı vd., 2010):

$$
R E K_{G}=\prod_{i=1}^{N}\left[\frac{P_{T U R}}{P_{i} * e_{i, T U R}}\right]^{w_{i}}
$$

Burada, $\mathrm{w}_{\mathrm{i}^{\prime}}, \mathrm{P}_{\text {TUR }}, \mathrm{P}_{\mathrm{i}}, \mathrm{e}_{\mathrm{i}, \text { TUR' }}$ ve $\mathrm{N}$, sırasıyla i ülkesinin Türkiye'nin reel kur endeksindeki ağırlığını (Türkiye'nin dış ticaretindeki ağırlığı alınmıştır), Türkiye'nin fiyat endeksini, i ülkesinin fiyat endeksini, 
i ülkesi parasının TL cinsinden karşılığını ve analize dahil edilen ülke sayısını göstermektedir. Reel kurun endeks değerinin artması TL'nin reel olarak değerlenmesi anlamına gelmektedir.Buradan hareketle, reel kur endeksi denge değerinin üzerine çıkmışsa, Türk Lirası reel olarak denge değerinin üzerinde değerli demektir. Dolayısıyla bu makalede aşırı değerli reel kur ve aşırı değerli TL kavramları aynı duruma işaret ettiklerinden dönüşümlü olarak kullanılmıştır.

Aşırı değerli reel kur, ülkenin ihracat ürünlerinin fiyat rekabeti gücünü azaltırken, ithalatı artırıcı rol oynamakta, uzun süren aşırı değerlenme dönemleri yerli sanayinin ucuzlayan ithal mallarıla rekabette zorlanmasına sebep olabilmektedir. Diğer taraftan, kurun aşırı değersiz konumda olması, ihracatı teşvik ederken, ithalatı pahalılaştırmakta, dış ticaret açığını küçültücü yönde etki yapmaktadır. Ancak değersiz kurun ekonomi üzerinde olumsuz etkileri de bulunmaktadır. İthal girdileri pahalılaştırarak enflasyonu körüklemekte (özellikle Türkiye gibi ithal ara mallarının ve yatırım mallarının üretimde payının yüksek olduğu ülkelerde), dış borçların yerel para karşıığını artırarak borç yükünü ağırlaştırmaktadır.

Williamson tarafından ortaya atılan ve IMF'nin uzun yıllar benimsediği "Vaşington Uzlaşısı (Washington Consensus)"na göre, reel kurun aşırı değer kaybı da, aşırı değer kazancı da büyümeye zarar verir. Aşırı değerlenme cari açı̆̆ı artırarak, tekrar dengeye gelmesi için düşük büyüme oranlarını gerekli kılar. Değersiz kur ise ekonominin aşırı ısınmasına yol açarak enflasyonu artırır ve bu da yatırım ortamını bozarak orta vadede büyümeye zarar verir (Williamson, 1990). Reel döviz kurunun dengeden pozitif veya negatif yönlü sapmasının ihracat, ithalat, GSYH, yatırım ve tasarruflar üzerinde olumsuz etkilerini gösteren bazı çaIışmalar bulunmaktadır (Cottani et. al. (1990), Ghura ve Grennes (1993)). Diğer taraftan, Rodrik (2008) ile Berg ve Miao $(2010)^{2}$, çok sayıda ülkeyi kapsayan panel veri analizleriyle reel kurun aşırı değerli olmasının büyüme üzerinde negatif, değersiz olmasının ise büyüme üzerinde pozitif etkisinin olduğunu göstermişlerdir. Rodrik (2008)'e göre, aşırı değerli kur, ödemeler dengesini bozucu etkileriyle makroekonomik istikrarsızlığa yol açmaktadır; ancak düşük ve orta gelirli ülkelerde etkiler bunun ötesine geçmektedir. Düşük ve orta gelirli ülkelerde ticarete konu malları üreten sektörler piyasa başarısızlıklarından ve kurumsal zayıflıklardan daha fazla etkilenmektedir; bu durum, sektörlerin ekonomik dönüşümünü ve çeşitlendirmeyi engellemektedir. Reel kurun değer kaybı bu sektörleri destekleyerek ekonomik büyümeye katkıda bulunmaktadır. Yüksek gelirli ülkelerde bu bağlantı kopmaktadır.
Easterly (2005) de çeşitli ülkeleri içeren literatür taramasında, reel kurun önemli ölçüde değer kazanmış olmasının büyüme üzerinde olumsuz etkileri olduğu sonucuna varmaktadır.

Bu çalışmada, reel kurun denge değerinin hesaplanmasına ilişkin literatür özetlendikten sonra Türkiye'nin reel kurunun denge değerleri ve denge değerinden sapmaların boyutları analiz edilecektir.

Reel kurdaki değişimlerin ekonomik temellerdeki değişimlerden mi, yoksa spekülatif hareketlerden mi kaynaklandığı bir politika müdahalesine ihtiyaç duyulup duyulmayacağının belirlenmesi açısından önemlidir. Reel kur değişimleri, örneğin verimlilik farklılıkları gibi ekonomik temellerden kaynaklanıyorsa, kurun uzun vadeli denge değeri değişiyor demektir ve bir çok ekonomiste göre politika müdahalesine intiyaç duyulmayabilir (Edwards (1988), Hussain (2009), Alper ve Sağlam (2000)). Diğer taraftan, spekülatif sebeplerle reel kur denge değerinden ayrılıyorsa, bu durumun ekonomik istikrar üzerinde olumsuz etkileri olacaktır.

Kriz literatüründe çok sayıda çalışma, reel döviz kurunun aşırı değerlenmesinin krizlerin önemli bir öncü göstergesi olduğu yargısına varmaktadır. Kaminsky ve Reinhart (1999), çeşitli tarihlerde ve ülkelerde gerçekleşmiş 76 adet para krizini ve 26 adet bankacılık krizini inceledikleri çalışmalarında, hem bankacılık, hem para krizlerinin bir yıl kadar öncesinde reel kurun aşırı değerlendiğini, para krizi öncesinde reel kurun normal zamandaki değerine göre $\% 20$ aşırı değerli hale geldiğini tespit etmektedirler. Yazarlara göre bunun verimlilik artışları veya tercihlerin değişimi gibi ekonomik temellerden kaynaklanmadığını krizle beraber yaşanan yüksek oranlı devalüasyonlar göstermektedir. Krizler öncesinde reel kurun aşırı değerli hale geldiğini gösteren diğer çalışmalar arasında Kaminsky vd. (1998), Kibritçioğlu (2004), Burkart ve Coudert (2002), Bussierre ve Fratzschen (2006), Kibritçioğlu ve Kibritçioğlu(2004), Schnatz (1998),Özatay (2000), Özkan (2005) sayılabilir.

Reel kurun çok sayıda değişkeni etkilemesi, çok sayıda değişkenden etkilenmesi ve krizlerle bağlantısı, politika yapıcıların "ince ayar" yapma ihtiyacını ortaya çıkarmaktadır. Bunun için de reel kurun denge değerinden ne kadar saptığının, kura müdahaleye ihtiyaç olup olmadığının, ihtiyaç varsa bu ihtiyacın ne boyutta olduğunun çok iyi tespit edilmesi gerekmektedir. Konunun bir başka boyutu ise, reel kuru etkileyen değişkenlerin ve izlenebilecek politikaların ne gibi sonuçlarının olacağının analiz edilmesidir. 


\section{LITERATÜR TARAMASI}

Satın alma gücü paritesi yaklaşımı uluslararası serbest ticaretin varlığı ve sıfır taşıma maliyetleri varsayımı altında, farklı ülkelerin dünya piyasalarında sattıkları malların fiyalarının eşitleneceğini söyler. Mutlak satın alma gücü paritesi teorisi farklı ülkelerin ürettikleri ürünlerin nominal kurla birbirlerine çevrildiğinde tek fiyatının olacağını belirtirken, göreli satın alma gücü paritesi yaklaşımı, fiyatların değişim oranlarının eşitleneceğini öngörür. Göreli satın alma gücü paritesi yaklaşımına göre bir ülkenin nominal kuru her dönem kendisi ile ticaret ortaklarının enflasyon farkları kadar artar (ya da enflasyon ticaret ortaklarınınkinden düşükse, nominal kur enflasyon farkları kadar düşer), bir başka deyişle reel kur her zaman sabit kalır. Ancak gerçekte, bu durumun her zaman gerçekleşmediği, reel kurun pek çok ülkede ekonomik temeller veya spekülasyon kaynaklı olarak değiştiği görülmektedir.

Konu ile ilgili literatürde sıklıkla Balassa-Samuelson etkisi test edilmektedir (Balassa (1964) ve Samuelson (1964)). Balassa-Samuelson etkisi, bir ekonomide ticarete konu malları üreten sektörler ile ticarete konu olmayan malları üreten sektörler arasında işçi ücretlerinin eşitleneceği varsayımından hareket eder. Bu varsayım altında, ticarete konu sektörlerde gözlemlenecek bir verimlilik artışı (ticaret ortaklarınınkine göreli olarak), bu sektörlerde işçi ücretlerini artıracak, bu artış, ticarete konu olmayan malları üreten sektörlerin işçi ücretlerinde de artışa yol açacak, maliyet artışları ticarete konu olmayan malların fiyatlarını artıracak ve reel kur değer kazanacaktır. Bir başka deyişle, ihraç mallarında göreli verimliliklerini artıran ülkelerin reel kuru değerlenir. Balassa-Samuelson etkisi ile bağlantılı bir diğer teori "Penn etkisi" olarak anılmaktadır. Balassa-Samuelson'un da tespit ettiği gibi, yüksek gelirli ülkelerde ticarete konu olmayan malların fiyatı göreli olarak daha yüksektir. "Penn etkisi" yaklaşımına göre bu durum, ekonomi geliştikçe, milli gelir arttıkça ticarete konu olan malları üreten sektörlerin verimliliklerini daha hızlı artırmalarından kaynaklanmaktadır.

Reel kuru tahmin eden istatistiksel ve ekonometrik modeller satın alma gücü paritesine dayalı basit yöntemlerden genel denge modellerine kadar çeşitlilik göstermektedir. Isard (2007) ve Kibritçioğlu ve Kibritçioğlu(2004) kur tahminlerinde kullanılan yöntemlerin bir literatür taramasını vermektedir.

Satın alma gücü paritesini temel alan yaklaşıma göre kurun uzun dönemli denge değeri olarak ekonominin genel olarak dengede olduğu, kurun aşırı değerli veya değersiz olmadığının kabul edildiği bir dönem alınır. Denge değerinden sapmalar bu dönemin değerine göre ölçülür. Bu dönem genellikle reel kur hesabının baz yılı olmaktadır (Ahlers ve Hinkle(1999)). Flood ve Taylor (1996) ve Isard (2007), çok sayıda ülkeyi inceledikleri çalışmalarında, nominal kurun kısa vadede olmasa da, çok uzun vadede ülkenin ticaret ortaklarıyla enflasyon farkı kadar arttığını bulmuşlardır; bu sonuçlar, göreli satın alma gücü paritesi teorisini destekler niteliktedir. Bu yaklaşımın zayıflığı denge reel kurunun zaman içinde değişmeyeceğini varsayması ve denge değerinden kısa ve orta vadeli sapmaları göz ardı etmesidir.

Bu zayıflı̆ı gidermek üzere zaman değişimli parametre modelleri kullanılmaktadır. Bu modellerde, reel kurun denge değerinin zaman içinde verimlilik farklılıkları, milli gelir artışı farklılıkları, teknoloji değişimleri gibi etkenlerle değişebildiği gerçeğinden hareketle, reel kurun trend değeri hesaplanır ve bu seri uzun dönem denge değeri serisi olarak kullanılır (Ahlers ve Hinkle(1999), Kibritçioğlu ve Kibritçioğlu(2004)). Reel kurun trend değeri, reel kur serilerine Hodrick -Prescott(1997), Kalman, Band-pass vs. filtreler kullanılarak elde edilir.

Bunların dışında makroekonomik değişkenlerle reel kur ilişkisini bulma hedefine yönelik olarak kurulan, tek denklemden oluşan zaman serisi modelleri ile sistem denklemi modelleri de sıklıkla kullanılmaktadır.Reel kurun bağımlı değişken olduğu modellerde, reel kuru etkileyebilecek çeşitli makro- ekonomik temeller bağımsız değişkenler olarak modele alınmaktadır. Bu modellerde Johansen Eşbütünleşme Denklemlerinin, Engle-Granger yönteminin, VAR'ın, VEC'in ve ARDL'nin en yaygın olarak kullanılan tahmin yöntemleri olduğu görülmektedir (Joyce ve Kamas (2003), Atasoy ve Saxena (2006), Kibritçioğlu ve Kibritçioğlu (2004), MacDonald ve Ricci(2003), Hussain (2009), Ersoy (2010), Dinçer ve Kandil (2011), Algirei (2011), Chowdhury (2011)). Ayrıca panel veri yöntemleri de kullanılmaktadır (Berg ve Miao (2010), Rodrik (2008), Courdet ve Couharde (2009), Carrera ve Restout (2008)).

Tahmininde yaşanan zorluklar sebebiyle daha az kullanılan bir model grubu ise temel denge kuru (fundamental equilibrium exchange rate-FEER) yaklaşımıdır. Williamson (1994) tarafından geliştirilmiş ve IMF tarafından yapılan analizlerde de kullanılmıştır. $\mathrm{Bu}$ yaklaşımla, ekonominin iç dengesini (potansiyel milli gelirin üretildiği tam istihdam seviyesi, sıfır çıktı açı̆̆ı) ve dış dengeyi (sıfır cari açık veya hedeflenen, uzun vadeli tasarruf-yatırım dengesini, borç 
sürdürülebilirliğini sağlayan cari açık) sağlayan reel kur seviyesi, denge değeri olarak kabul edilir. Bu tür çalışmalara Fevzioğlu (1997), Bayoumi vd. (2005), You ve Sarantis (2011), Cline ve Williamson (2011) örnek verilebilir. FEER yöntemi çeşitli açılardan eleştirilmektedir. Özellikle gelişmekte olan ülkelerin ekonomileri genellikle bir geçiş sürecinde olduğundan potansiyel milli gelirin tanımlanmasında ve hesaplanmasında zorluklar yaşanmaktadır (Courdet ve Couharde, 2007). Potansiyel milli gelir hesaplansa bile bir ekonominin tam istihdam seviyesine ve sıfır (veya hedef, sürdürülebilir) cari açık durumuna aynı anda ulaşması gerçekçi bulunmamaktadır(Rusek,2012). FEER genellikle eş anlı denklem sistemleri ile tahmin edilmeye çalışıldığından veri kısıtlarıyla da sıklıkla karşılaşılmaktadır (Rusek, 2012).

Ayrıca, ekonominin bütününü modelleyen genel denge modelleri de kullanılmaktadır. Genel denge modelleri, makroekonomik davranışın bütüncül bir resmini çizmesi, içsel değişkenleri birbiriyle etkileşimini gözönünde bulundurarak tahmin etmesi gibi avantajlara sahiptir. Ancak her ülkenin bu tür genel denge modelleri bulunmamakta, bulunanların bazılarında ise kısa dönemli tahmin amacına yönelik olarak tasarlanmış olmaktadır. Genel denge modellerinin bir dezavantajı da, elde edilecek sonuçların, sisteme gelecek şokların niteliği ve süresi hakkında yapılacak varsayımlara çok duyarlı olmasıdır (Isard, 2007).

Reel kur üzerinde etkili olan iktisadi temelleri çeşitli iç faktörler ve dış faktörler olarak da sıralamak mümkündür. İç faktörler arasında (verimlilik, teknolojik gelişmeler, devlet harcamaları, ithalat kısıtları, ihracat teşvikleri, tarifeler, Merkez Bankası rezervleri vb.) ve dış faktörler arasında (dış dünya ile faiz oranları farkı, sermaye akımları, dış ticaret hadleri, cari işlemler dengesi vb.) sayılabilir. İç faktörlerden bazıları doğrudan devlet politikaları ile yönlendirilebilirken (kamu harcamaları, ithalat kısıtlamaları, ihracat teşvikleri, Merkez Bankası rezervleri gibi) bazıları genellikle devletin doğrudan müdahalesinin dışında kalmaktadır (verimlilik ve teknolojik gelişmeler gibi) (Chowhury (2011), Algieri (2011)). Tabi devletin mikroekonomi politikalarıly verimlilik ve teknolojik gelişmeler üzerinde de etkili olması mümkündür.

Reel kurun denge değerinden ne kadar saptığının ölçülmesinde bir başka yaklaşım ise ticarete konu malları üreten sektörlerin rekabet güçlerinin ölçülmesidir (Isard, 2007). Lipschitz ve MacDonald (1992)'nın, İtalya'yı inceleyen çalışmalarında gösterildiği üzere, 1979-1988 döneminde İtalyan Liretinin
Alman Markı karşısında önemli ölçüde değer kazanmasına rağmen, birim iş gücü maliyeti/fiyat oranı düşmüş, ülkenin ticarete konu sektörleri Almanya karşısında rekabet güçlerini artırmışlardır.

Gerek tek denklem, gerekse genel denge modellerinde model tahmin edilip de bu modelden denge reel kuru hesaplanırken, bağımsız değişkenlerin de denge değerlerinin kullanılmasına dikkat edilmelidir. MacDonald ve Ricci (2003) bu konuya dikkat çekmektedir. Uzun dönem denge reel kurunun hesaplanabilmesi için denklemdeki bağımsız değişkenlerinde cari değerlerinin değil, kendi uzun dönem denge değerlerinin (sürdürülebilir değerlerinin) kullanılması gerekir. Bunun için bağımsız değişkenlerin de Hodrick -Prescott, Kalman, Band-pass vs. filtreler kullanılarak denge değerleri bulunmalı ve tahminlerde bu denge değerleri kullanılmalıdır.

Bu çalışmada, TL reel kurunun denge değeri ve denge değerinden sapmanın boyutları iki yöntemle değerlendirilecektir. Zaman değişimli parametre modelleri çerçevesinde reel kurun eğiliminden sapmaları Hodrcik-Presscot yöntemiyle ayrıştırılacaktır. Sonrasında TL'nin reel kur denklemi 1999Ç2-2012Ç2 verileri kullanılarak FMOLS ve VEC yöntemiyle tahmin edilecektir. Makalenin 3. Bölümünde Türk Lirası reel kurunun son dönemdeki seyri anlatılmaktadır. 4. Bölümde zaman değişimli parametre modeli çerçevesinde trend analizleri sonucunda elde edilen bulgulara yer verilmiştir. 5 . Bölümde FMOLS ve VEC denklemlerinin verileri, yöntem ve sonuçları, 6 . Bölümde ise denge reel kur hesabının sonuçları açıklanmaktadır. Son bölümde makalede ulaşılan sonuçlar özetlenmektedir.

\section{TÜRK LIRASI REEL KURUNUN SON ON YILDAKI SEYRI}

Son yıllarda Türk Lirasının reel değeri çok tartışılan konulardan biri olmuştur. Şekil 1'de, Türkiye Cumhuriyet Merkez Bankası (TCMB) tarafından hesaplanan, 2003 yılı bazıı TÜFE ve ÜFE Bazlı Reel Efektif Döviz Kuru endekslerinin 2003 yılından bu yana izlediği seyir görülmektedir. 2003 yılının birinci çeyreğinde 90,6 olan TÜFE bazlı endeks değeri 2007 yılının 4. çeyreğinde 130,4'e kadar çıkmış, bir başka deyişle \%44 oranında değerlenmişti. Bu tarihten itibaren küresel krizin etkisiyle değer kaybetmeye başlayan TL reel kur endeksi \%14 oranında değer kaybederek 2009 yılı birinci çeyreğinde 111,9'a kadar düşmüş, bu tarihten sonra tekrar artmaya başlayarak 2010 yılının son çeyreğinde 129,3'e kadar çıkmıştır. 


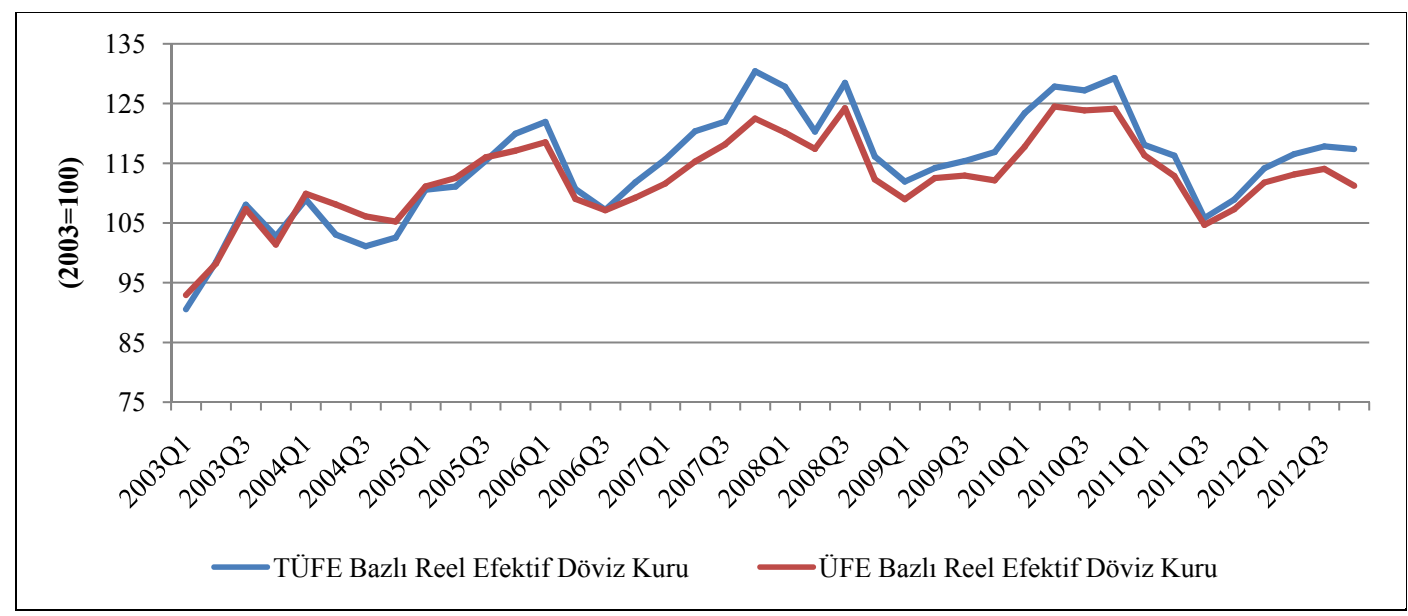

Şekil 1: TÜFE ve ÜFE Bazlı Reel Efektif Döviz Kuru (2003=100), (Kaynak: TCMB)

Reel döviz kurunda 2007 yılının 4. Çeyreğine kadar gözlemlenen değerlenmede, küresel büyümenin risk iştahını, dolayısıyla sermaye akımlarını hızlandırması, bu kapsamda diğer gelişmekte olan ülkelerle birlikte Türkiye'ye de yabancı kaynak girişinin artması etkili olmuştu.

2008 yılının başlarından itibaren kendini göstermeye başlayan küresel krizinin yarattığı panik ve belirsizlik ortamında duraksayan küresel sermaye akımlarından Türkiye de etkilenmiştir. Ancak sonrasında, ABD başta olmak üzere gelişmiş ekonomilerin krizin etkilerini hafifletmek için parasal genişlemeye gitmesiyle beraber artan küresel likidite, gelişmekte olan ülkelerin krizden daha hızlı toparlanmaları sebebiyle söz konusu ülkelere akmıştır. Diğer gelişmekte olan ülkelerle birlikte, Türkiye de, yüksek faiz oranları, sağlam bankacılık sistemi ve düşük hane halkı borçlanma oranlarına sahip, güvenilir bir piyasa olması sebebiyle uluslararası sermaye akımları için cazip bir ülke olmuştur. Artan kısa vadeli sermaye girişleri reel kurun değerlenmesine, cari açığın artmasına bunun da ötesinde vade-kur uyumsuzluklarının derinleşmesine ve finansal istikrarın bozulmasına sebep olmuştur.

Küresel kriz karşında, Türkiye Cumhuriyet Merkez Bankası da ekonomiyi canlandırıcı önlemler alarak likiditeyi artırmış, 2008 yılının Kasım ayından itibaren yaklaşık bir yıllık süreçte politika faizlerini 1025 baz puan indirerek gelişmekte olan ülkeler arasında en erken faiz indirmeye başlayan ve toplamda en fazla faiz indiren merkez bankası olmuştur. Ancak yine de Türkiye'nin faiz oranları gelişmiş ülkelerdeki ve pek çok gelişmekte olan ülkedeki faiz oranlarının çok üstünde olduğundan sermaye girişleri ve buna bağlı olarak TL'deki değerlenme devam etmiştir.
2010 yılının son çeyreğine gelindiğinde güçlü sermaye girişleri ile birlikte cari dengedeki bozulma ve kredi genişlemesindeki hızlanma önlem alma gereğini artırmıştır. TCMB Kasım 2010'dan itibaren yeni para politikası çerçevesini fiyat istikrarı yanında finansal istikrarı da hedefleyen politika tedbirlerini artırmış, bir yandan kısa vadeli faizleri düşük tutarak sermaye girişlerini caydırmayı amaçlayan, diğer yandan da zorunlu karşılık oranlarını artırarak kredi artış hızını yavaşlatmayı hedefleyen bir stratejiyi uygulamaya koymuştur. Ayrıca, finansal sistemin yükümlülüklerinin vadesinin uzatılması da destekleyici bir amaç olarak benimsenmiştir. Aralık 2010'u izleyen aylarda uygulanan politikalarla faizler düşürülmüştür. Uygulanan makro iktisadi tedbirler paralelinde iç talebin yavaşlamasına bağlı olarak 2011 yılının ikinci çeyreğinden itibaren büyüme hızı da düşmeye başlamıştır. 2011 yılı üçüncü çeyreğine kadar yürütülen bu politikalar ve konjonktürel gelişmeler neticesinde TL reel olarak 2007'nin son çeyreğindeki en yüksek seviyesine göre \%18,8 civarında değer kaybetmiş̧ir.

Kurdaki değer kaybının enflasyonist etkilerinin giderilmesi amacıyla Ekim 2011'de parasal sıkılaştırmaya giden TCMB, Şubat 2012'de iç ve dış talepteki dengelenme gözlemlenmesi sebebiyle faiz koridorunu daraltmış, bu da piyasalara faizlerin düşmesi şeklinde yansımıştır. 2011 yılı son çeyreğinde başlayan reel kur değerlenme trendi 2012 yılı boyunca da devam etmiştir. 2012 yılı sonu itibariyle 2011 yılı 3. çeyreğine göre TL reel kuru tekrar \%11,7 değer kazanmış durumdadır.

Bir başka deyişle TL reel olarak 2012 yılı sonu itibariyle, 2007 yılının 4. çeyreğindeki en yüksek seviyesine göre yaklaşık \%9,3 değer kaybetmiş durumdadır. TL'nin 2003 yılından itibaren süren yüksek reel 
artışları göz önünde bulundurulduğunda, ilk bakışta, TL'nin denge değerine göre hala bir miktar değerli olduğu düşünülebilir. Ancak, sonraki bölümlerde gösterilen denge hesaplamaları bu öngörüyü desteklememektedir.

\section{TÜRK LIIRASI REEL KURUNUN TRENDi}

Reel kur literatüründe, kurun denge değerinden sapmaları ölçmede kullanılan yöntemlerden bir bölümü de zaman değişimli parametre modelleridir. Zaman değişimli parametre modelleri, reel kurun denge değerinin zaman içinde değişebileceğinden hareket eder. Bu tür modellerde genellikle reel kurun denge değeri bulmak üzere seri trend ve çevrimsel parçalarına ayrıştırılır. Bu bölümde, zaman değişimli parametre yaklaşımı çerçevesinde, Hodrick-Presscott (1997) filtresi kullanılarak reel kur serisi trend ve çevrimsel kısımlarına ayrıştııılmıştır.

Hodrik-Prescott filtresi makroekonomik zaman serilerinin çevrimsel ve büyüme bileşenlerinden oluştuğunu ve büyüme bileşeninin zaman içinde düzgün şekilde değiştiği varsayımına dayanır. Bu amaçla, Hodrik-Prescott filtresi denklem 1'de verilen kayıp fonksiyonunu minimize eder (filtre, zaman seri- si $\left(y_{t}{ }_{t}^{\prime}\right.$ nin, büyüme oranını $\left(g_{t}\right)$ ayrıştııır ve kalan çevrimsel bileşendir).

$\operatorname{Min}_{g_{t}}\left\{\sum_{t=1}^{T}\left(y_{t}-g_{t}\right)^{2}+\lambda \sum_{t=1}^{T}\left[\left(g_{t}-g_{t-1}\right)-\left(g_{t-1}-g_{t-2}\right)\right]^{2}\right\}$

Kayıp fonksiyonunda yer alan $\lambda$ parametresi zaman serisinin büyüme bileşenindeki değişimin kayıp maliyetini artıran bir parametredir; bir başka deyişle, $\lambda$ parametresi artırıldıkça, daha düz bir Hodrick-Prescott trendi elde edilmektedir. Bu çalışmada Hodrick ve Prescott (1997)'un çeyreklik veriler için tavsiye ettiği şekilde $\lambda=1600$ alınmıştır.

Şekil 2'de TCMB TÜFE bazlı reel kur serisinin Hodrick-Prescott filtresi kullanılarak ayrıştııımış trend ve çevrimsel bileşimleri görülmektedir. Şekilden, TL reel kurunun son dönemde trend değerine yakınsadığı gözlemlenmektedir. Diğer taraftan, reel kurun trend değerinin 2009 yılı ikinci çeyreğine kadar düzenli olarak arttığı, son dönemde azalma eğilimine döndüğü gözlemlenmektedir. 1998 yılının ilk çeyreğinde 89,16 seviyesinde olan trend, 2009 yılının ikinci çeyreğinde 120,12 ile en yüksek değerine ulaşmış, sonrasında küçük oranda da olsa azalmaya başlayarak 2012'nin ikinci çeyreğinde 116.28 olarak gerçekleşmiştir.

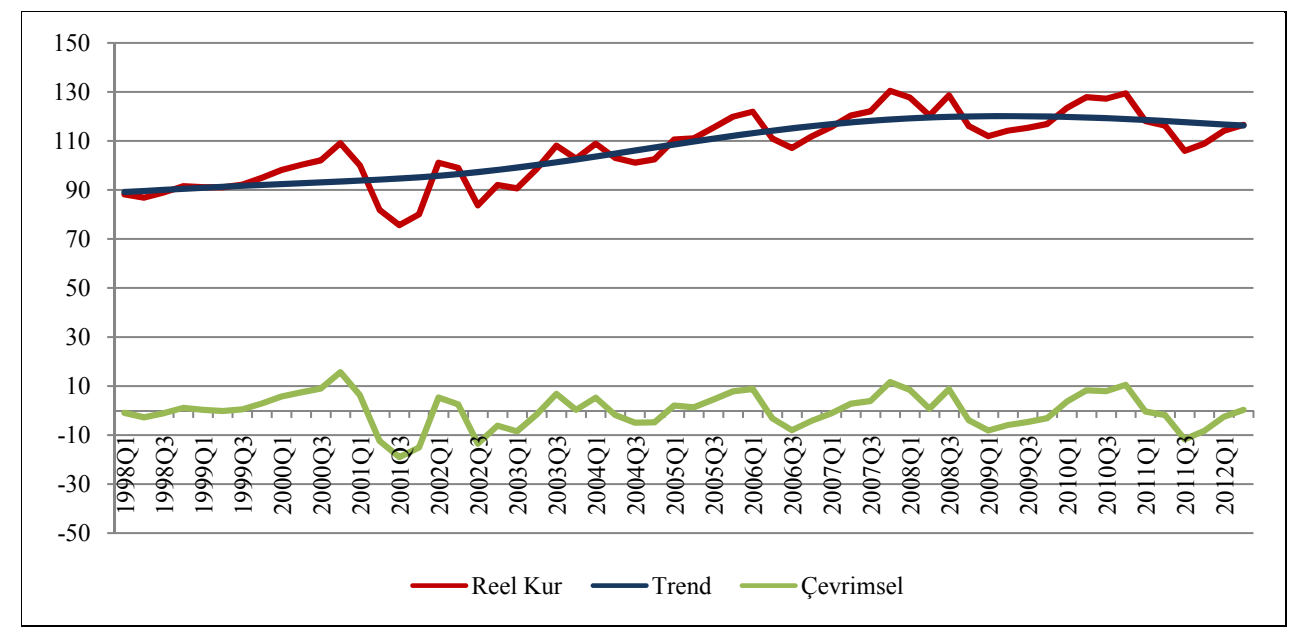

Şekil 2: Reel Efektif Döviz Kurunun (TÜFE Bazlı) Trend ve Çevrimsel Bileşenleri, (Kaynak: TCMB)

Yine TCMB tarafından hesaplanan, ÜFE bazlı reel kur serisinin de TÜFE bazlı seriye çok benzer eğilimler gösterdiği tespit edilmektedir. 


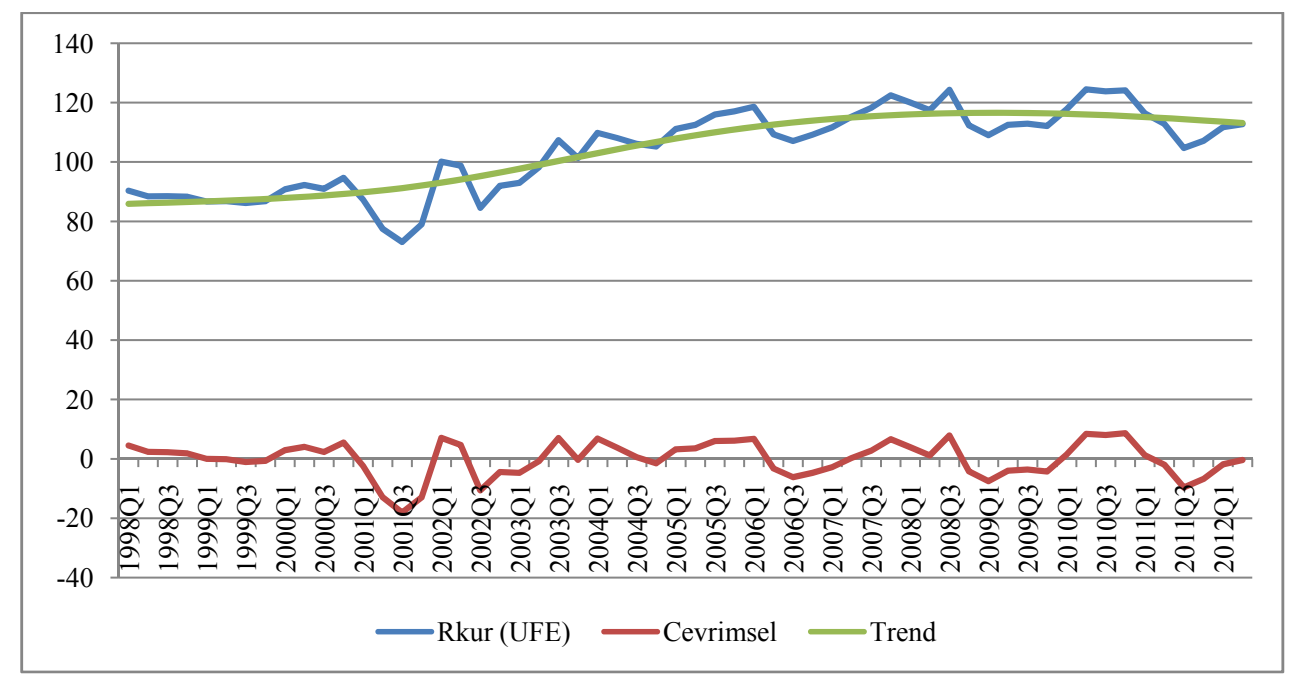

Şekil 3: Reel Efektif Döviz Kurunun (ÜFE Bazlı) Trend ve Çevrimsel Bileşenleri (Kaynak: TCMB)

TCMB, 2003 yılından 2012 yılının ilk çeyreğine kadar birim iş gücü maliyeti bazlı reel kur serilerini de hesaplamıştır. Seriler 2003 yııından geriye gitmediğinden analizimiz de 2003 yılından başlatılmıştır. Şekil 4, birim iş gücü maliyeti bazlı reel kur serisinin trend ve çevrimsel bileşenlerini vermektedir.

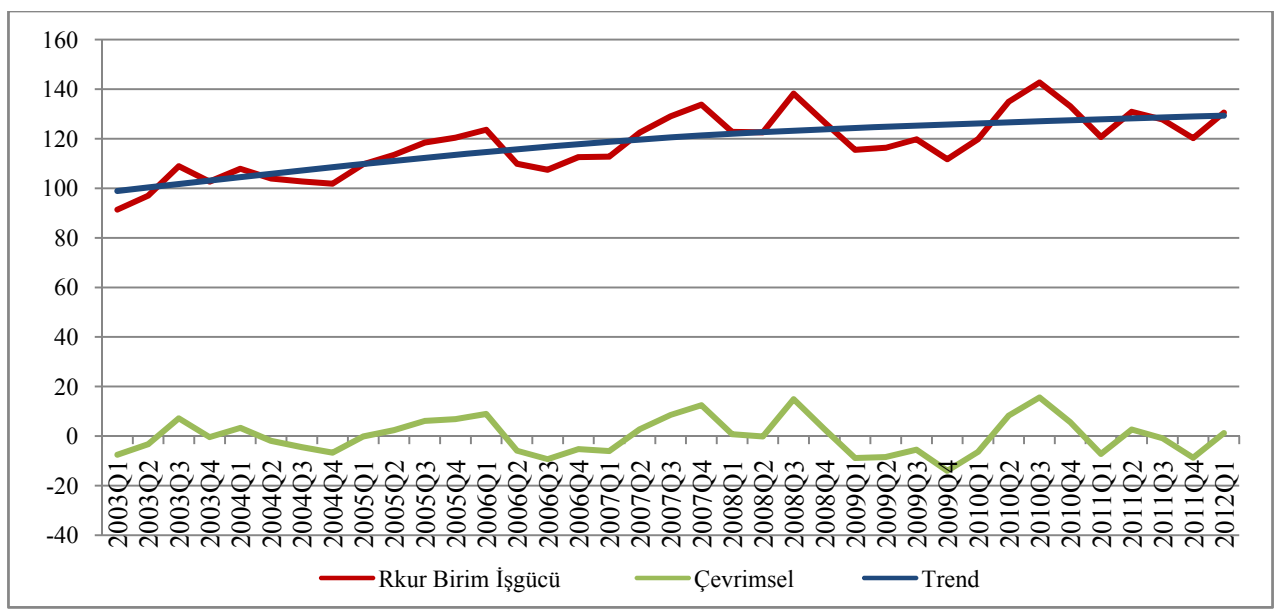

Şekil 4: Reel Efektif Döviz Kurunun (Birim İşgücü Maliyeti Bazlı) Trend ve Çevrimsel Bileşenleri (Kaynak: TCMB)

Birim iş gücü maliyeti bazlı reel kur serilerinin de son dönemde trend değerine yaklaştığı görülmektedir. Bu serilerin TÜFE bazlı seriden farkı, TÜFE bazıı serinin trendi 2009 yılının ikinci çeyreğinden itibaren azalışa döndüğü halde, birim iş gücü maliyetli serinin trendinin hep artış yönünde oluşudur. Bu da TL'nin son dönemdeki reel değer kaybına rağmen, iş gücü maliyetleri açısından rekabet gücünde önemli bir iyileşme olmadığını düşündürmektedir.

\section{VERILER VE YÖNTEM}

Reel kur literatürü temelde reel kurun uzun ve kısa dönemdeki makroekonomik belirleyicilerinin incelenmesi ve kurun denge düzeyinden sapmalarının modellenmesi üzerinde yoğunlaşmaktadır. Literatürde pek çok farklı yöntemin ve bağımsız değişkenin kullanımına rastlamak mümkündür.

Reel kurun denge değerini tahmine yönelik oluşturulan ekonometrik modellerin sıkıkla kullandıkları bağımsız değişkenler 5 grup altında toplanabilir.

Balassa-Samuelson etkisi, verimliliği artan ülkenin ticarete konu malları üreten sektörlerinde iş gücü maliyetlerinin artacağını, faktör fiyatlarının eşitleneceği varsayımı altında bu artışın ticarete konu olmayan malları üreten sektörlere de sirayet edeceği, ticarete konu olmayan malların fiyatlarının artmasıyla reel kurunun değerleneceğini öngörür. Bu etkiyi tes- 
pit etmek üzere genellikle ülkenin ve ticaret ortaklarının verimlilikleri, milli gelirleri ile yerel ve ticaret ortaklarının göreli olarak ticaret konu olan malların fiyatları/ticarete konu olmayan malların fiyatları kullanılmaktadır. Chowdhury (2011), teknoloji ve verimlilik gelişmeleri değişkenini bu amaçla kullanmıştır. Kibritçioğlu ve Kibritçioğlu (2004) ile Atasoy ve Saxena (2006) Türkiye için Balassa-Samuelson etkisinin varlığını kanıtlayamamışlardır. Buna karşılık Mac Donald ve Ricci (2004), Kumar (2010), Algieri (2011), ülkeler arasındaki verimlilik farklarının reel kurun uzun dönem dengesini değerlenme yönünde etkilediğini farklı ülkeler ve dönemler için göstermişlerdir. Egert (2012)'de verimlilik farkının işareti belirsizdir.

Bir talep faktörü olarak devlet harcamalarının artması, daha çok ticarete konu olmayan mallara talebi artırdığından, bu malların fiyatlarının artmasına yol açacak ve bu da kura değerlenme yönünde baskı yapacaktır. Literatürde kurulan çeşitli modellerde, genellikle GSYH'ya oran olarak, kamu harcamaları, kamu kesimi dengesi, bütçe dengesi,kamu tüketim harcamaları, kamu yatırım harcamaları kullanılmaktadır. Algieri (2011), devlet kesimini temsil etmek üzere bütçe harcamaları/bütçe gelirleri oranını kullanmıştır.Kibritçioğlu ve Kibritçioğlu (2004), Atasoy ve Saxena (2006), Carrera ve Restout (2008), Elhendawy (2012) kamu harcamaları veya kamu harcamaları/GSYH değişkenlerini kullanarak reel kuru değerlendirme yönündeki etkinin varlığını göstermiş̧lerdir. Hussain (2009) hükümetin tüketim harcamalarını bu amaçla kullanmış ve tüketim harcamalarındaki artışın reel kuru değerlenme yönünde etkilediğini göstermiştir. Kumar (2010)'da iseilgili değişkenin katsayısı anlamlı değildir.

Dış ticaret hadlerindeki değişimin reel kur üzerindeki olası etkisi belirsizdir. Burada iki çeşit etki söz konusudur: gelir etkisi ve ikame etkisi. Dış ticaret hadlerinin ülkenin lehine gelişmesi, satın alma gücünü artırarak ticarete konu olmayan mallara yönelik harcamaları ve bu malların fiyatlarını artırarak reel kurun değerlenmesine yol açar. Diğer yandan, göreli olarak ucuzlayan ithal mallara yönelik ikame etkisi reel kura değer kaybettirme yönünde etkide bulunur. Net etki gelir ve ikame etkilerinin hangisinin baskın olduğuna göre ortaya çıkar. Dış ticaret hadlerindeki artışın reel kura değer kaybı yönünde etki yaptığını bulan çalışmalar arasında (Kibritçioğlu ve Kibritçioğlu (2004), Doroodian vd. (2002), Atasoy ve Saxena (2006), Hussain (2009)) sayılabilir. Diğer taraftan, Alper ve Sağlam (2000), Joyce ve Kamas (2003), Algieri (2011), Berg ve Miao (2010), Chowdhury (2011) dış ticaret hadlerindeki artışla reel kurun değer kazanması arasında ilişki bulmuştur.
Literatürde, dışa açıklık değişkenin reel kuru değer kaybı yönünde etkileyeceği beklentisi hakimdir. Dış ticaretin önündeki engellerin kalkması, örneğin tarifelerin düşmesi, ithal malların fiyatlarını ucuzlatacak, bu mallara artan talep, dış ticaret dengesinin sağlanması için reel kurun değer kaybetmesini gerektirecektir. Dışa açıklık değişkeni olarak genellikle dış ticaret hacminin GSYH'ya oranı kullanılmaktadır (Kibritçioğlu ve Kibritçioğlu (2004),Carrera ve Restout (2008), Alper ve Sağlam (2000), MacDonald ve Ricci (2003), Algieri (2011), Berg ve Miao (2010), Özlale ve Yeldan (2002), Hussain (2009)). Atasoy ve Saxena (2006), kur kontrollerini ve dış ticaret üzerindeki kontrolleri değişken olarak kullanmıştır.

Sermaye akımları ve faiz farkları özellikle son dönemde uluslararası spekülatif sermayenin ve sermaye hareketlerinin çok artması sebebiyle önem kazanmıştır. Faiz oranları diğer ülkelere göreli olarak artan ülkelere sermaye akımları artmakta, bu da yerel paraya talebi artırarak kurun değerlenmesine sebep olmaktadır. Diğer taraftan, faiz oranlarındaki artış risk primindeki artıştan kaynaklanıyor ve ülkenin riskliliği algılamaları artıyorsa, tersine faiz artışları sermaye çıkışına ve reel kurda değer kaybına da sebep olabilmektedir. Söz konusu etkileri ölçmek üzere ülkenin gösterge niteliğindeki çeşitli nominal ve reel faiz oranları ile dünya reel faiz oranlarını temsil etmek üzere genellikle ABD'nin gösterge faiz oranları kullanılmaktadır. Sermaye akımlarına ilişkin olarak ise toplam sermaye girişlerinin yanısıra, doğrudan yabancı yatırımlar, portföy yatırımları ve diğer yatırımlar alt kalemlerinde ülkeye sermaye giriş çıkışları kullanılmaktadır. Merkez Bankası rezervleri de birçok makalede değişken olarak kullanılmış olup, rezervleri artan Merkez Bankasının kuru aşırı değer kayıplarına karşı daha rahat savunabilmesi, dolayısıyla reel kuru değerlenme yönünde etkilemesi beklenir. Kibritçioğlu ve Kibritçioğlu (2004), Türkiye örneğinde dünya reel faiz haddi, doğrudan yabancı yatırımlar/GSYH ve sermaye girişi, TCMB net yurt dışı varlıkları değişkenlerini kullanmış ve reel kur ile arasında anlamlı bir ilişki bulamamıştır. MacDonald ve Ricci (2003), Güney Afrika Cumhuriyeti örneğinde ve Elhendawy (2012) Suudi Arabistan örneğinde Merkez Bankası net dış varlıklarındaki artışın reel kuru değerlenme yönünde etkilediğini bulmuştur. Hussain (2009), Pakistan'da sermaye girişlerinin reel kuru değerlenme yönünde etkilediğini göstermiştir. Özlale ve Yeldan (2002), Türkiye örneğinde bankacılık sektörü tarafından kullanılan dış kredilerin reel kuru değerlenme yönünde etkilediğini tespit etmiştir. 
Ersoy (2010), literatürdeki yaygın Neo-Klasik yaklaşımın tersine fiyat eşitlenmesi değil, kar eşitlenmesi yaklaşımını benimsemiştir. Yazar, uluslararası göreli fiyatların belirlenmesinde göreli üretim maliyetlerinin ve firmaların kar güdülerinin önemine dikkat çekmiştir. Bu yaklaşıma göre, uluslar arası ticaret maliyetlerle yönlendirilmektedir ve fiyat mekanizmaları ülkeler arasında ticaret dengesini sağlayamaz. Yazar, Engle-Granger Eşbütünleşme testi, Johansen Eşbütünleşme Testi, VEC kullanarak kurduğu modeller sonucunda, Türkiye örneğinde imalat sanayi reel birim iş gücü maliyetleri/ticaret ortaklarının imalat reel sanayi birim işgücü maliyetleri oranındaki artışların reel kuru değerlenme yönünde etkilediği sonucuna ulaşmıştır. Ticaret ortaklarıyla faiz oranları farkı ise reel kur üzerinde istatistiksel açıdan anlamlı bir etkiye sahip değildir.

Bu çalışmada, Türkiye reel kurunun denge değerini hesaplamak üzere tamamen değiştirilmiş en küçük kareler (fully modified ordinary least squares-FMOLS) ve vektör hata düzeltme (VEC) modelleri kullanılarak tahminler yapılmıştır. Sonrasında uzun vadeli ilişkiyi temsil eden FMOLS modeli üzerinden kurun denge değeri hesaplanmıştır.

Veriler 1999Ç2-2012Ç2 dönemi çeyreklik verilerini kapsamaktadır.Denklemlerde çok sayıda değişken denenmiş, katsayısı anlamlı çıkmayan değişkenler ile yüksek çoklu bağlantıya yol açan değişkenler modelden çıkarılmıştır.Türkiye'nin GSYH'sı ve büyüme oranları, kamu tüketimi, kamu yatırımları, kamu harcamaları, toplam yatırımlar/GSYH, Türkiye'nin reel faiz oranları, sanayi üretimi, TCMB döviz, altın ve toplam rezervleri, M2 para arzı, cari denge/GSYH, ihracat ve ithalat miktar ve fiyat endeksleri, dış ticaret hadleri, Türkiye'nin dış ticaret ortaklarının ticaret ağırlıklı GSYH'ları, (hizmetler dahil ve hariç) dış ticaret hacmi/ GSYH, sermaye girişleri/GSYH, doğrudan yabancı yatırımlar/GSYH, bankaların kullandığı kısa vadeli krediler, dolar nominal kuru standart sapması, OECD ülkelerinin birim iş gücü maliyetleri, Türkiye bankalararası faiz oranı ile ABD para piyasası faiz oranları farkı, TCMB tüketici güven endeksi denklemlerde denenen değişkenlerdir. Türkiye'nin ticaret partnerleriyle olan göreli birim iş gücü maliyeti farkının hesaplanabilmesi için birim işgücü maliyet endeksi serisi oluşturulmuştur. Değişkenlerden M2 para arzı, cari denge, sermaye girişleri, doğrudan yabancı yatırımlar, TCMB rezervleri, bankaların kullandığı uzun vadeli krediler, TCMB elektronik veri dağıtım sisteminden, OECD ülkelerinin birim iş gücü maliyetleri OECD veri tabanından, ABD para piyasası faiz oranları ve Türkiye bankalararası faiz oranları Economist Intelligence
Unit veri tabanından, kamu tüketimi, kamu yatırımları, kamu harcamaları verileri Maliye Bakanlığından, diğer veriler TÜiK'ten alınmıştır. Türkiye'nin birim iş gücü maliyetleri TüiK verileri kullanılarak tarafımızdan hesaplanmıştır. TÜiK "İstihdam ve Ücret Veri Tabanı"ndan imalat sanayi üretimde çalışılan saat başına brüt ücret endeksi (w) ile çalışılan saat endeksi (L) çarpılmış, imalat sanayi üretimine $(\mathrm{Q})$ bölünmüştür. Bir başka deyişle (BiM=w.L/Q) olarak formüle edilebilir.Sonrasında OECD ülkelerinin iş gücü maliyet endeksi ile Türkiye'nin birim iş gücü maliyeti endeksi oranlanmıştır.

\section{ANALIZ SONUÇLARI}

Reel kurun modellenmesi için öncelikle yukarıda açıklanan bütün değişken serilerine "ElliottRothenberg-Stock Point Optimal" birim kök testi ve $\mathrm{Ng}$-Perron birim kök testi uygulanmıştır.

Literatürde sıklıkla kullanılan Augmented Dickey Fuller (ADF) ve Phillips Perron (PP) testlerinin test gücü açısından sorunlara yol açtığı gösterilmiştir. Değişkenlerin otoregresif kökü büyüdükçe $A D F$ ve $P P$ testlerinin alternatif hipotezi reddetme gücünün düşük olduğu belirtilmektedir (DeJong, vd., 1992). Ayrıca serinin büyük bir negatif hareketli ortalama köküne sahip olması durumunda testlerin boş hipotezi reddetme yönünde sapmalı olduğu görülmektedir (Schwert, 1989). KPSS birim kök testinin de sınırlı örneklemde benzer sorunlara sebep olduğu Caner ve Killian (2001) tarafından gösterilmiştir. Genel anlamda ADF ve PP testlerinin I(1)'e yakın I(0) alternatiflerini ayırt etme gücünün düşük olduğu, diğer bir deyişle bu birim kök testlerinin kalıcı (persistent) durağan serileri durağan olmayan serilerden ayırt edemediği belirtilmektedir. Elliott-Rothenberg-Stock (1996) ve Ng-Perron (2001) testleri bu sorunları giderdiği için tercih edilmiştir.

Birim kök testlerinin sonuçları Ek-1'de yer almaktadır. Denklemlerde durağanlık problemi oluşmaması için farklı durağanlık düzeyine sahip olan ancak yüksek açıklama gücüne sahip olabilecek bir takım değişkenlerin modelin dışında bırakılması gerekmiştir. Sadece I(1) olan değişkenler denklemlerde kullanılmıştır . Bütünleşme derecesi I(1) olduğu halde katsayısı anlamsız çıkan değişkenler ve diğer değişkenlerle çoklu-kolinearite sorununa yol açan değişkenler de denklemden çıkarılmıştır.

En son ulaşılan tahmin denklemi aşağıdaki şekilde gösterilebilir:

$R K U R T \ddot{U F E}=\beta_{0}+\beta_{1}$ SermayeGirişiGSYH $+B_{3}$ GoreliULCOE $C D+\beta_{4}$ LnDolarGSYH $+\beta_{5} L n D$ ş̧Tic GSYH $+\beta_{6}$ KuklaTCMB 
TÜFE bazlı reel kur endeksi (RKURTÜFE) bağımlı değişken olmak üzere, bağımsız değişkenler Türkiye'ye yurt dışından toplam sermaye girişlerinin GSYH'ya oranı (SermayeGïrişGSYH), OECD ülkelerinin birim iş gücü maliyetlerinin Türkiye'ninkine oranı (GöreliULCOECD), logaritmik formda dolar cinsinden Türkiye'nin GSYH'si (InDolarGSYH), yine logaritmik formda Türkiye'nin dış ticaretinin GSYH'ya oranı (LnDışTicGSYH), TCMB politikaları için kukla değişken (KuklaTCMB) olarak tanımlanmıştır.
Değişkenler arasında eşbütünleşme olup olmadığının, eğer varsa eşbütünleşme derecesinin tespit edilmesi için ayrıca Johansen Eşbütünleşme Testi kullanılmıştır. Johansen Eşbütünleşme Testi, tek denklem değil sistem tahmini yaptığından ve birden çok eşbütünleşme ilişkisi olduğunda bunu tespit edebilen bir yöntem olduğundan tercih edilmiştir. Test sonuçları iki adet eşbütünleşme ilişkisinin istatistiksel olarak anlamlı olduğunu göstermektedir. Test sonuçları Tablo 1'den görülebilir.

Tablo 1: Johansen Eşbütünleşme Testi

\begin{tabular}{|c|c|c|c|c|}
\hline \multicolumn{5}{|c|}{ Örneklem (Uyarlanmış): 1999Q4 2012Q2 } \\
\hline \multicolumn{5}{|c|}{ Gözlem sayısı: 51 Uyarlamalardan Sonra } \\
\hline \multicolumn{5}{|c|}{ Trend Varsayımı: Lineer Deterministik Trend } \\
\hline \multicolumn{5}{|c|}{$\begin{array}{l}\text { Seriler: RKURTUFE GORELIULCOECD KUKLATCMB LNDOLARGSYH LNDISTICGDP } \\
\text { SERMAYEGIRIŞGDP }\end{array}$} \\
\hline \multicolumn{5}{|c|}{ Gecikme Aralıkları (Birinci Farklarda): 1 to 1} \\
\hline \multicolumn{5}{|c|}{ Sınırlanmamış Eşbütünleşme Sıra Testi (Trace) } \\
\hline Hipotez Edilen & & Trace & 0.05 & \\
\hline Eşbütünleşme Sayısı & Öz Değer & İstatistik & Kritik Değer & Olasılık** \\
\hline Hiç * & 0.724 & 150.594 & 95.754 & 0.000 \\
\hline En fazla ${ }^{*}$ & 0.577 & 84.881 & 69.819 & 0.002 \\
\hline En fazla 2 & 0.357 & 41.016 & 47.856 & 0.188 \\
\hline En fazla 3 & 0.207 & 18.531 & 29.797 & 0.527 \\
\hline En fazla 4 & 0.120 & 6.675 & 15.495 & 0.616 \\
\hline En fazla 5 & 0.003 & 0.164 & 3.841 & 0.686 \\
\hline En fazla 6 & 0.724 & 150.594 & 95.754 & 0.000 \\
\hline \multicolumn{5}{|c|}{ Trace testi 0.05 seviyesinde 2 eşbütünleşme ilişkisinin varlığını göstermektedir. } \\
\hline \multicolumn{5}{|c|}{$\begin{array}{l}\text { * } 0.05 \text { seviyesinde hipotezin reddedildiğini gösterir. }{ }^{* *} \text { MacKinnon-Haug- } \\
\text { Michelis (1999) p-değerleri }\end{array}$} \\
\hline \multicolumn{5}{|c|}{ Sınırlanmamış Eşbütünleşme Sıra Testi (Maksimum Öz Değer) } \\
\hline Hipotez edilen & & Maks-Öz Değer & 0.05 & \\
\hline Eşbütünleşme Sayısı & Öz Değer & İstatistiği & Kritik Değer & Olasılık** \\
\hline Hiç * & 0.724 & 65.713 & 40.078 & 0.000 \\
\hline En fazla $1^{*}$ & 0.577 & 43.865 & 33.877 & 0.002 \\
\hline En fazla 2 & 0.357 & 22.485 & 27.584 & 0.197 \\
\hline En fazla 3 & 0.207 & 11.856 & 21.132 & 0.562 \\
\hline En fazla 4 & 0.120 & 6.511 & 14.265 & 0.549 \\
\hline En fazla 5 & 0.003 & 0.164 & 3.841 & 0.686 \\
\hline En fazla 6 & 0.724 & 65.713 & 40.078 & 0.000 \\
\hline
\end{tabular}

Eşbütünleşme ilişkisinin tahmin edilmesi için iki yöntem kullanılmıştır; Tamamen Değiştirilmiş En Küçük Kareler (Fully Modified Ordinary Least SquaresFMOLS) ve Vektör Hata Düzeltme (Vector Error Correction-VEC). VEC metodu, değişkenler arasında hem kısa, hem de uzun vadeli ilişkilerin görülmesi için çok kullanılan, değişkenler arasındaki gecikmeli bağlantıları göz önünde bulunduran, eşbütünleşme ilişkisinin tahmininde etkin bir yöntemdir. Diğer taraftan, Phillips ve Hansen (1990) tarafından geliş- 
tirilen FMOLS yöntemi, I(1) değişkenler arasındaki eşbütünleşme ilişkilerinin tahmininde değişkenlere ilişkin denklemlerin hata terimleri arasındaki eş dönemli korelasyonları da gözönünde bulundurduğundan ikinci derece sapmaları (second order bias) da ortadan kaldırmaktadır. Phillips ve Hansen (1990), geliştirdikleri parametrik olmayan bir yöntemle, değişkenleri, hata terimleri arasındaki korelasyonlardan arındırmakta ve böylece eş anlılık sapmaları giderilmektedir. "icçsellik EKK tahmincisinde ikinci dereceden sapma yaratmaktadır. Bu durumda EKK tahmincisi tutarlı olmasına karşın limit dağılımı merkezden uzaklaşır. Tam değiştirilmiş En Küçük Kareler tahmincisi, klasik EKK tahmincisine iki düzeltme yapılarak elde edilmektedir" (Güloğlu, 2012). Phillips ve Han- sen (1990), Monte-Carlo simulasyonları ile, En Küçük Kareler (EKK), Hata Düzeltme ve FMOLS yöntemlerini karşılaştırmış, EKK'nın en sapmalı yöntem olduğunu, Hata Düzeltme modelinin genellikle iyi sonuç vermekle birlikte yine de biraz sapmalı olduğunu, FMOLS'in sonlu örneklemlerde çok küçük bir sapma gösterdiğini ve VEC'ten daha az sapmalı olduğunu göstermiştir. Örneklem büyüklüğünün 50 olduğu durumda bile hem hata düzeltme yöntemi, hem de FMOLS yöntemi iyi sonuçlar vermektedir.

Bu çalışmamızda, önce uzun vadeli eş bütünleşme ilişkisi Tamamen Değiştirilmiş En Küçük Kareler(Fully Modified Ordinary Least Squares (FMOLS)) ile tahmin edilmiş, sonrasında VEC yöntemi ile de kısa ve uzun vadeli ilişkiler bir arada gözlemlenmeye çalışılmıştır.

Tablo 2: Reel Efektif Döviz Kuru Tahmini, FMOLS

\begin{tabular}{|c|c|c|c|c|}
\hline \multicolumn{5}{|c|}{ Bağımlı Değişken: RKURTUFE } \\
\hline \multicolumn{5}{|c|}{ Yöntem: Tamamen Değiştirilmiş En Küçük Kareler (FMOLS) } \\
\hline \multicolumn{5}{|c|}{ Örneklem (uyarlanmış): 1999Q3 2012Q2 } \\
\hline \multicolumn{5}{|c|}{ Gözlem sayısı: 52 uyarlamalardan sonra } \\
\hline \multicolumn{5}{|c|}{ Eş bütünleşme denklemi deterministikleri: $C$} \\
\hline \multicolumn{5}{|c|}{$\begin{array}{l}\text { Uzun vadeli kovaryans tahmini (Prewhitening with lags }=1 \text { from AIC } \\
\text { maxlags }=3 \text {, Bartlett kernel, Newey-West automatic bandwidth = } \\
17.4275, \mathrm{NW} \text { automatic lag length }=3 \text { ) }\end{array}$} \\
\hline Değişken & Katsayı & Std. Hata & t-istatistiği & Olasılık \\
\hline GORELIULCOECD & -10.532 & 1.555 & -6.772 & 0.000 \\
\hline KUKLATCMB & -16.282 & 1.096 & -14.862 & 0.000 \\
\hline SERMEYEGIRIŞGSYH & 0.792 & 0.100 & 7.909 & 0.000 \\
\hline LNDIŞTICGSYH & 6.757 & 2.776 & 2.434 & 0.019 \\
\hline LNDOLARGSYH & 25.950 & 0.817 & 31.769 & 0.000 \\
\hline C & -17.809 & 8.180 & -2.177 & 0.035 \\
\hline R-kare & \multicolumn{4}{|c|}{0.874} \\
\hline Uyarlanmış R-kare & \multicolumn{4}{|c|}{0.860} \\
\hline Regresyon Std. Hatası & \multicolumn{4}{|c|}{4.959} \\
\hline Durbin-Watson istat. & \multicolumn{4}{|c|}{1.480} \\
\hline
\end{tabular}

FMOLS denkleminin sonuçları Tablo 2'de sunulmaktadır.

Tamamen Değiştirilmiş En Küçük Kareler Modeli kullanılarak oluşturulan uzun vadeli modelde, TCMB TÜFE bazlı reel kur endeksi bağımlı değişken olarak ve sermaye girişlerinin GSYH'ya oranı (SermayeGirişGSYH), OECD ülkelerinin birim iş gücü maliyetlerinin Türkiye'ninkine oranı (GöreliULCOECD), logaritmik formda dolar cinsinden Türkiye'nin GSYH'sı (InDolarGSYH), yine logaritmik formda Türkiye'nin dış ticaretinin GSYH'ya oranı (LnDışTicGSYH) bağımsız değişkenler olarak alınmıştır. Ayrıca Merkez Bankasının 2010 yılı Aralık ayından itibaren uyguladığı yeni para politikasını temsil etmek üzere kukla değişken tanımlanmıştır. Regresyon analizinin sonuçlarına göre; Türkiye'nin dolar cinsinden GSYH'sının \%1 artması reel kur endeksinde (değerlenme yönünde) 0,26 puan artışa yol açmaktadır. Bu durum, Balas-
sa-Samuelson etkisinin Türkiye için geçerli olduğunu göstermektedir. Literatürdeki pek çok ampirik çalışma büyümesi ve verimliliği artan ülkelerin reel kurunun değerlendiğini göstermektedir. Dış Ticaret Hacmi/GSYH Oranı oranında meydana gelen \%1 artış reel kur endeksinde ortalama 0,07 puan artışa yol açmaktadır; bir başka deyişle, TL'ye değer kazandırma yönünde etki etmektedir. Türkiye'ye gelen yabancı sermaye akımlarının GSYH'ya oranında 1 puanlık artış, reel kur endeksini 0,8 puan civarı artırmaktadır. Yurt dışından sermaye girişlerinin TL'ye talebi artırarak TL'de değerlenme baskısı yarattığı görülmektedir. OECD ülkelerinin Türkiye'ye göreli olarak iş gücü maliyetleri endekslerinin oranının bir birimlik artışı reel kurda 10,5 puan değer kaybına yol açmaktadır. Bir başka deyişle, söz konusu ülkelerin rekabet gücünün azalmasına, Türkiye'nin rekabet gücü artışına yol açmaktadır. Merkez Bankasının son dönem politikaları 
için tanımlanan kukla değişkenin katsayısının negatif ve anlamlı olması TCMB politikalarının son dönemde TL reel kurunun değer kaybetmesinde etkili olduğunu göstermektedir.

Buradan hareketle, bir sonraki aşama olarak değişkenler arasında uzun dönem dengesi ile kısa dönem dinamikleri arasında ayrım yapmada ve kısa dönem dinamiklerinin belirlenmesi amacıyla da kullanılan bir sistem yöntemi olan Vektör Hata Düzeltme (Vector Error Correction-VEC) modeli kurulmuştur. VEC modeli kurulurken, zayıf içsellik testleri ile hangi değişkenlerin içsel, hangilerinin dışsal olduğuna bakılmış, dış ticaret hacmi/GSYH dışındaki değişkenlerin dışsal olduğu sonucuna varılmıştır. İçsellik için yapılan LR Testi sonuçları Ek-2'de yer almaktadır. Gecikme uzunluğu otokorelasyon LM testine göre kararlaştırılmıştır. Eşbütünleşme ilişkisinin kalıntıları FMOLS yöntemi ile bulunan eşbütünleşme denkleminin kalıntılarından alınmıștır. FMOLS eşbütünleşme yöntemi Johansen eşbütünleşme yöntemine ter- cih edilmiştir; FMOLS ikinci derece sapmaları ortadan kaldıran bir model olup, daha iyi sonuç alınmaktadır. Bu sebeple VEC modelinde uzun vadeli eşbütünleşme denkleminin kalıntıları sisteme Tablo 2'de ayrıntıları verilen FMOLS denklemin sonuçlarından verilmiştir. Buna göre tahmin edilen modelin sonuçları Tablo 3'de sunulmaktadır.

Denklemin kalıtınlarında otokorelasyon kalıp kalmadığı otokorelasyon LM testi ile sınanmıştır. Otokorelasyon olmadığı tespit edilmiştir. Dolayısıyla sonuçlara güvenilebilir. Test sonuçları Ek-3'te yer almaktadır.

Model sonuçları, kısa vadeli ilişkide de,yurt dışından sermaye girişlerinin reel kuru değerlenme yönünde etkilediğini göstermektedir. Merkez Bankasının politikaları TL reel kuruna değer kaybı yönünde etki yapmıştır. Hata teriminin katsayısı reel kurun denge değerinden sapmalarının yaklaşık \%77'sinin bir çeyreklik dönem içinde giderildiğini göstermektedir.

Tablo 3: Reel Efektif Döviz Kuru Tahmini, VEC

\begin{tabular}{|c|c|c|}
\hline \multicolumn{3}{|c|}{ Vektor Autoregresyon Tahmini } \\
\hline \multicolumn{3}{|c|}{ Örneklem (Uyarlanmış): 2000Q1 2012Q2 } \\
\hline \multicolumn{3}{|c|}{ Gözlem sayısı: 50 (Uyarlamalardan Sonra) } \\
\hline \multicolumn{3}{|c|}{ Standart hatalar ( ) \& t-İstatistikleri [ ] } \\
\hline & D(RKURTUFE) & D(LNDISTICGSYH) \\
\hline \multirow{3}{*}{ D(RKURTUFE(-1)) } & 0.021684 & 0.000129 \\
\hline & $(0.18427)$ & $(0.00171)$ \\
\hline & {$[0.11767]$} & {$[0.07496]$} \\
\hline \multirow{3}{*}{ D(RKURTUFE(-2)) } & -0.110517 & 0.001389 \\
\hline & $(0.16117)$ & $(0.00150)$ \\
\hline & {$[-0.68571]$} & {$[0.92611]$} \\
\hline \multirow{3}{*}{ D(RKURTUFE(-3)) } & -0.148974 & 0.000652 \\
\hline & $(0.14915)$ & $(0.00139)$ \\
\hline & {$[-0.99884]$} & {$[0.46983]$} \\
\hline \multirow{3}{*}{ D(RKURTUFE(-4)) } & -0.465284 & 0.004596 \\
\hline & $(0.14801)$ & $(0.00138)$ \\
\hline & {$[-3.14366]$} & [3.33739] \\
\hline \multirow{3}{*}{ D(LNDISTICGSYH(-1)) } & -11.53246 & -0.445724 \\
\hline & $(17.5993)$ & $(0.16374)$ \\
\hline & {$[-0.65528]$} & {$[-2.72217]$} \\
\hline \multirow{3}{*}{ D(LNDISTICGSYH(-2)) } & -10.19975 & -0.232744 \\
\hline & $(13.8496)$ & $(0.12885)$ \\
\hline & {$[-0.73647]$} & {$[-1.80628]$} \\
\hline \multirow{3}{*}{ D(LNDISTICGSYH(-3)) } & 5.127958 & -0.451510 \\
\hline & $(13.9554)$ & $(0.12984)$ \\
\hline & [0.36745] & {$[-3.47751]$} \\
\hline \multirow{3}{*}{ D(LNDISTICGSYH(-4)) } & -1.671414 & 0.240896 \\
\hline & $(16.4843)$ & $(0.15337)$ \\
\hline & {$[-0.10139]$} & [ 1.57073] \\
\hline \multirow{3}{*}{ C } & 15.85893 & 0.246347 \\
\hline & $(16.1155)$ & $(0.14993)$ \\
\hline & [0.98408] & {$[1.64304]$} \\
\hline
\end{tabular}

\begin{tabular}{|c|c|c|}
\hline \multirow{3}{*}{ LNDOLARGSYH } & -2.884545 & -0.069857 \\
\hline & (3.16906) & $(0.02948)$ \\
\hline & {$[-0.91022]$} & {$[-2.36933]$} \\
\hline \multirow{3}{*}{ KUKLATCMB } & -8.203576 & 0.080576 \\
\hline & (3.87159) & $(0.03602)$ \\
\hline & {$[-2.11892]$} & [2.23698] \\
\hline \multirow{3}{*}{ GORELIULCOECD } & -2.267167 & 0.035556 \\
\hline & $(5.33677)$ & $(0.04965)$ \\
\hline & {$[-0.42482]$} & [0.71611] \\
\hline \multirow{3}{*}{ SERMAYEGIRIŞGSYH } & 1.227854 & 0.004729 \\
\hline & $(0.41405)$ & $(0.00385)$ \\
\hline & [ 2.96549] & [1.22754] \\
\hline \multirow{3}{*}{ RESIDFMOLS(-1) } & -0.768129 & -0.001807 \\
\hline & $(0.28672)$ & $(0.00267)$ \\
\hline & {$[-2.67901]$} & {$[-0.67722]$} \\
\hline R-kare & 0.506053 & 0.773101 \\
\hline Uyr. R-kare & 0.317191 & 0.686345 \\
\hline Kalıntı Kareleri Toplamı & 1266.379 & 0.109617 \\
\hline Denklem Std. Hatası & 6.102987 & 0.056780 \\
\hline F-istatistiği & 2.679488 & 8.911246 \\
\hline Log Olabilirlik & -146.6542 & 77.85817 \\
\hline Akaike AIC & 6.693926 & -2.660757 \\
\hline Schwarz SC & 7.239693 & -2.114990 \\
\hline Ort. Bağımlı Değişken & 0.340111 & 0.008880 \\
\hline Std.Hata Bağımlı & 7.385722 & 0.101385 \\
\hline \multicolumn{2}{|c|}{ Determinant Kalıntı Kovaryansı (serb. der. uyr.) } & 0.089130 \\
\hline \multicolumn{2}{|c|}{ Determinant Kalıntı Kovaryansı } & 0.044720 \\
\hline \multicolumn{2}{|l|}{ Log Olabilirlik } & -61.64182 \\
\hline \multicolumn{2}{|l|}{ Akaike Bilgi Kriteri } & 3.735076 \\
\hline \multicolumn{2}{|l|}{ Schwarz Kriteri } & 4.826610 \\
\hline
\end{tabular}




\subsection{TL Reel Kuru Denge Değerinden Ne Kadar Uzakta?}

Reel kurun denge değerinin ekonomik temellerle belirlendiği varsayımı altında uzun vadeli denklemin reel kur için verdiği tahmin değerleri reel kurun denge değeri olarak kabul edilebilir. Burada dikkat edilmesi gereken nokta, Mac Donald ve Ricci (2003)'de de vurgulandığı gibi, reel kurun denge değeri hesaplanırken bağımsız değişkenlerin de denge değerinin alınmasıdır. Zira, reel kurun uzun vadeli denge değerinden sapmaları ya spekülatif vb. ekonomik temellerden kaynaklanmayan etkilerle, ya da reel kuru etkileyen ekonomik temellerin denge değerinden sapmaları sonucunda oluşur.

Bu sebeple, reel kurun denge değerini ve denge değerinden sapmaları hesaplamak üzere önce reel kuru etkileyen bağımsız değişkenlerin denge değerleri Hodrick-Prescott yöntemiyle serilerin trend ve çevrimsel bileşenleri ayrıştırılarak bulunmuş, söz konusu denge değerleri uzun vadeli eşbütünleşme denkleminde (FMOLS) yerine konarak reel kurun denge değeri hesaplanmıştır. Şekil5-8 arasında reel kur tahmininde kullanılan bağımsız değişkenler ve trendleri görülmektedir.

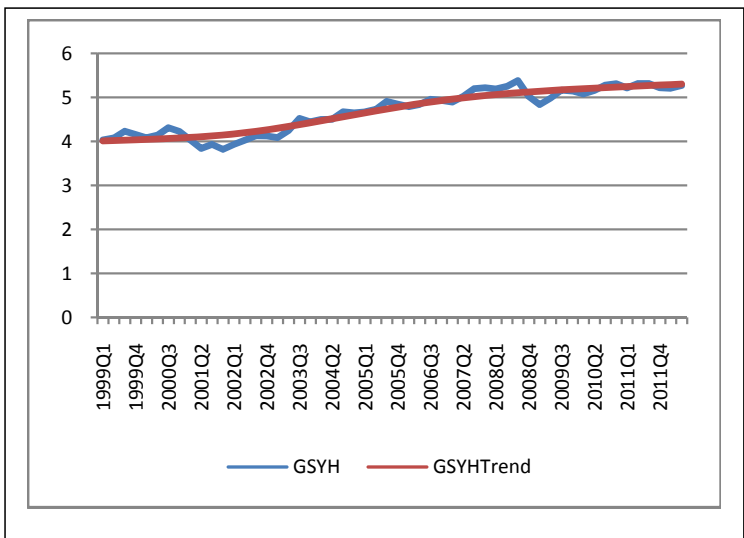

Şekil 5: GSYH (dolar) ve Trendi (logaritmik)

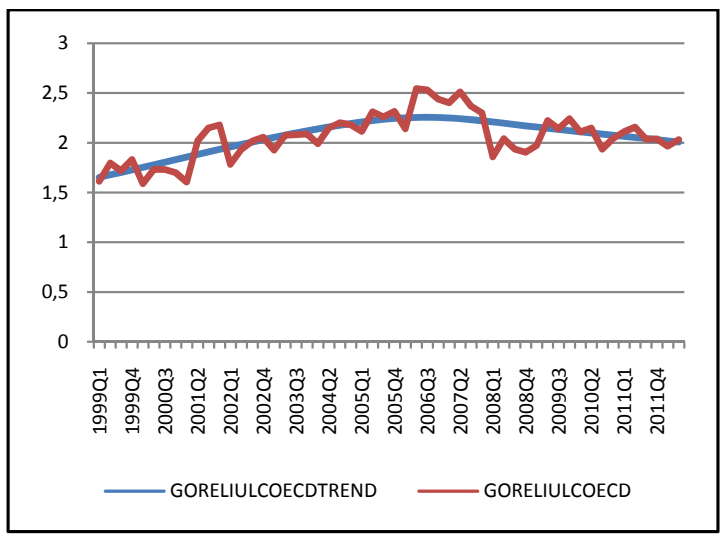

Şekil 7: OECD BiM/Türkiye BiM Endeksi ve Trendi

Bu şekilde hesaplanan, bağımsız değişkenlerin denge değerleri tablo 2'de detayları verilen uzun vadeli eşbütünleşme ilişkisini gösteren FMOLS modelinde yerine konmuştur. Bulunan değerler reel kurun denge değerini vermektedir.Şekil 9'da reel kurun denge değeri ve gerçekleşen değeri görülmektedir. Reel kurun denge değerinin 1999 'dan bu yana yükselen bir trend izlediği gözlemlenmektedir. Reel kur endeksi 1999 yılı başındaki 92,5 seviyesinden, 2010 yılının son çeyreğinde 126,4'e kadar yükselmiştir.

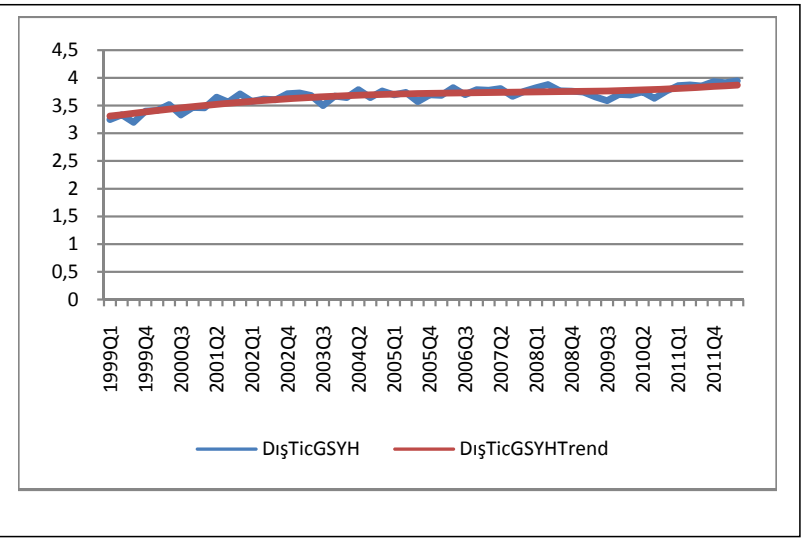

Şekil 6: Dış Ticaret /GSYH Oranı ve Trendi (logaritmik)

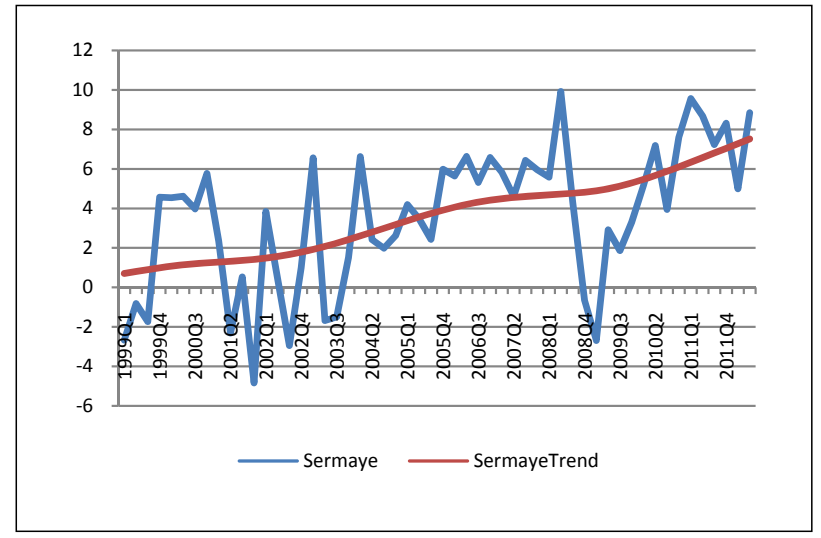

Şekil 8: Sermaye Girişleri/GSYH ve Trendi

Sonrasında TCMB'nin yeni para politikasının etkilerine bağlı olarak denge reel kuru düşüşe geçmiştir. Sonrasında 2011 yılının son çeyreğinden itibaren biraz yükselerek 2012 yılının ikinci çeyreğinde endeksin denge değeri 114,3 seviyesine yükselmiştir.

Özellikle son dönemde kurun denge değerine önemli ölçüde yakınsadığı gözlenmektedir.1999 Ç32002 Ç1 döneminde kurun denge değerinden sapmaları en yüksek seviyesine ulaşmıştır. Bu boyutta 
olmasa da kurun denge değerinden saptığı bir başka dönem de 2009 yılıdır. Her iki döneminde ekonomik kriz yılları olduğu dikkat çekmektedir. Ekonomik kriz öncesinde aşırı değer kazanan reel kur, krizle beraber değer kaybetmekte, denge değerinin de altına inmektedir. Çeşitli çalışmalarda dile getirilen, krizlerin öncesinde genelllikle kurun aşırı değerli hale geldiği, aşırı değerli kurun bir kriz öncü göstergesi olarak kullanabileceği bulgularının (Kaminsky vd. (1998), Kibritçioğlu (2004), Burkart ve Coudet (2002), Bussierre ve Fratzschen (2006), Kibritçioğlu ve Kibritçioğlu (2004), Schnatz (1998), Özatay (2000), Özkan (2005)) Türkiye verisiyle de doğrulandığı görülmektedir. Diğer dönemlerde denge değerinden sapmalar daha küçük boyutlarda kalmaktadır. Bir başka deyişle, ana- liz sonuçlarına göre, 2. bölümde bahsedilen, TL'nin 2003-2010 yılları arasında gözlemlenen yüksek oranIı değer kazançlarında reel kurun denge değerinin değişmesinin;milli gelirdeki ve dış ticaret hacmindeki artışgibi ekonomik temellerin etkisinin önemli olduğu, dengeden sapmaların özellikle son dönemde büyük oranlara ulaşmadığı gözlemlenmektedir.

TCMB'nin son dönem politikalarının reel kurun denge değeri üzerinde etkili olduğu görülmektedir. Bu noktada, "TCMB yeni para politikasına geçmeseydi denge reel kurunun alacağı değer ne olurdu?" sorusu sorulmuştur. Şekil 10'da görüleceği gibi, TCMB yeni para politikasının uygulanmaması durumunda kurun denge değeri yükselmeye devam edecek, TL önemli ölçüde değer kazanacak, endeksin denge değeri 130,7'ye kadar çıkacaktı.

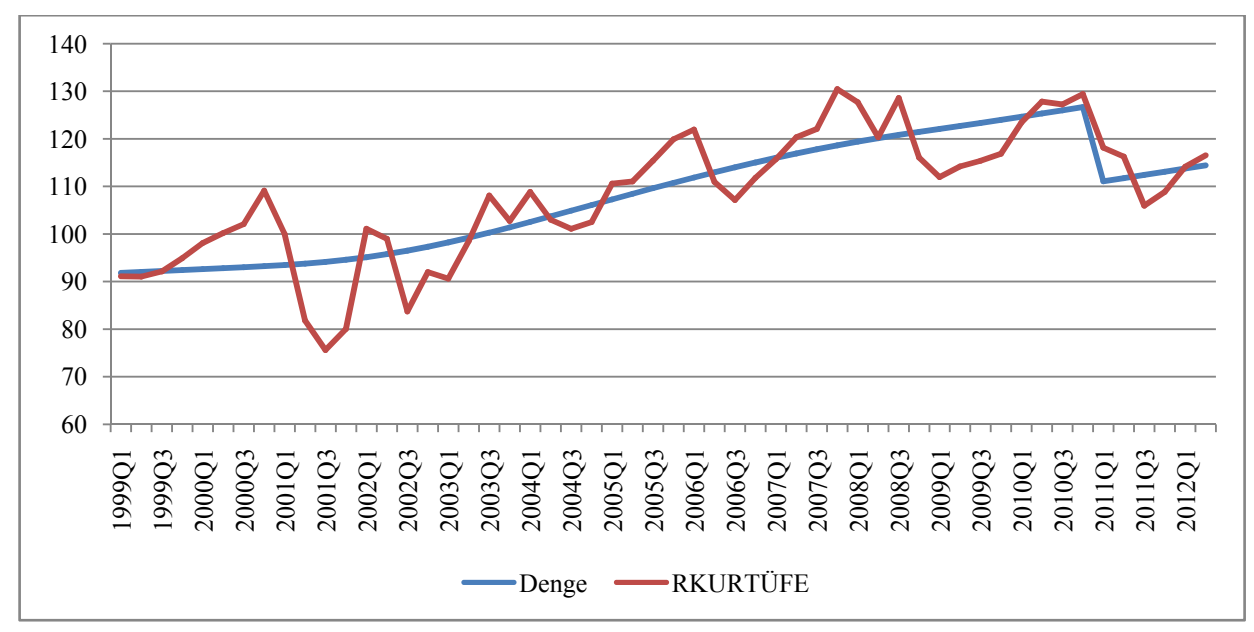

Şekil 9: Reel Kurun Denge Değeri ve Gerçekleşen Değerleri

\subsection{Genişletilmiş Analiz Sonuçları}

Önceki bölümde TÜFE bazlı reel döviz kuru için uygulanan denge değeri analizi, bu bölümde reel kurun ÜFE tanımlı olanı için de tekrarlanmış, böylece tanımdan kaynaklanan olası farklılaşmaların saptanması ve analizin güvenilirliğinin artırılması hedeflen- miş̧ir 5 . Şekil 11, ÜFE Bazlı reel döviz kuru kullanılarak yapılan denge değeri analizinin sonuçlarını göstermektedir. Görüldüğü üzere ÜFE bazlı reel döviz kuru da TÜFE bazlı kur gibi denge değerine yakınsamaktadır. Yine kriz dönemlerinde denge değerinden sapmalar artmaktadır ama sapmaların boyutu TÜFE bazlı

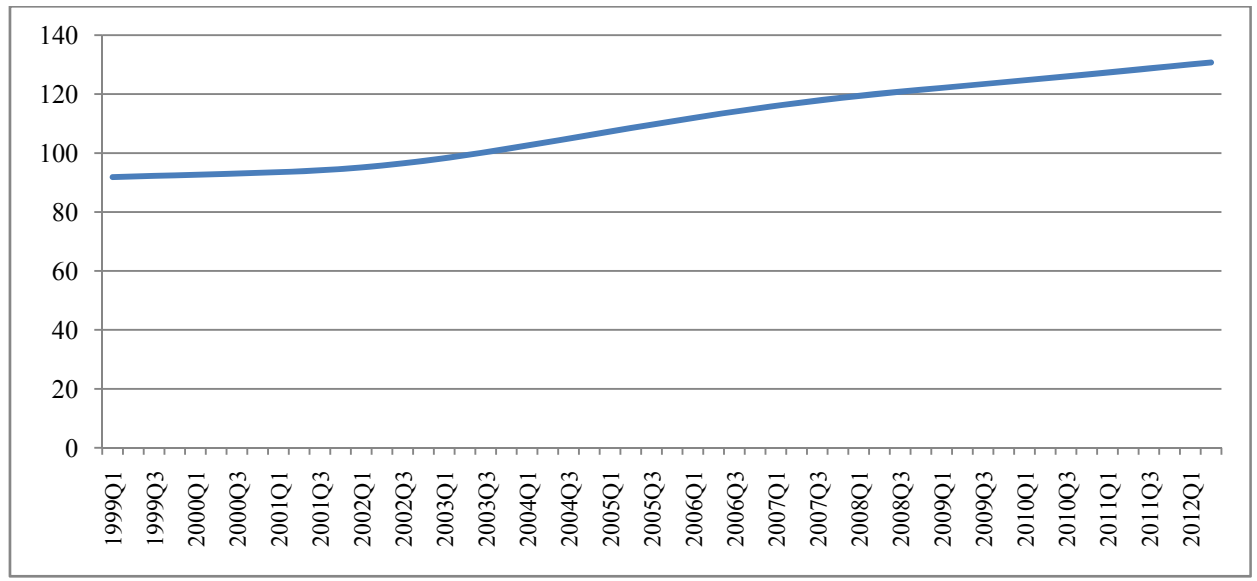

Şekil 10: Reel Kurun Denge Değeri (Beklenen-TCMB Yeni Para Politikasına Geçmeseydi) 
reel kurdakinden daha küçüktür.Merkez Bankasının son dönem politikalarının etkisi ÜFE bazlı reel kur denklemi üzerinde de görülmektedir.

Analizimizin bir diğer genişleme noktası olarak, Hodrick-Prescott filtresi yerine zaman serisinin çevrimsel bileşeninin sürekliliğini kısıtlayarak bu bileşeni izole eden band-pass (frekans) filtreleme yöntemi kullanılmıştır. Bu filtreleme tekniğinde temel mantık belli bir alt ve üst frekans limiti dışında kalan çevrimsel bileşenin filtrelenmesidir. Bunun için de verinin iki taraflı ağırlıklandırılmış hareketli ortalamasının hesaplanması gerekmektedir. Çalışmada, öncül (lead) ve gecikme (lag) ağırlıklarının değişmesine izin veren ve en çok kullanılan yöntemlerden biri olan, Cristiano ve Fitzgerald (2003) tarafından geliştirilen tam

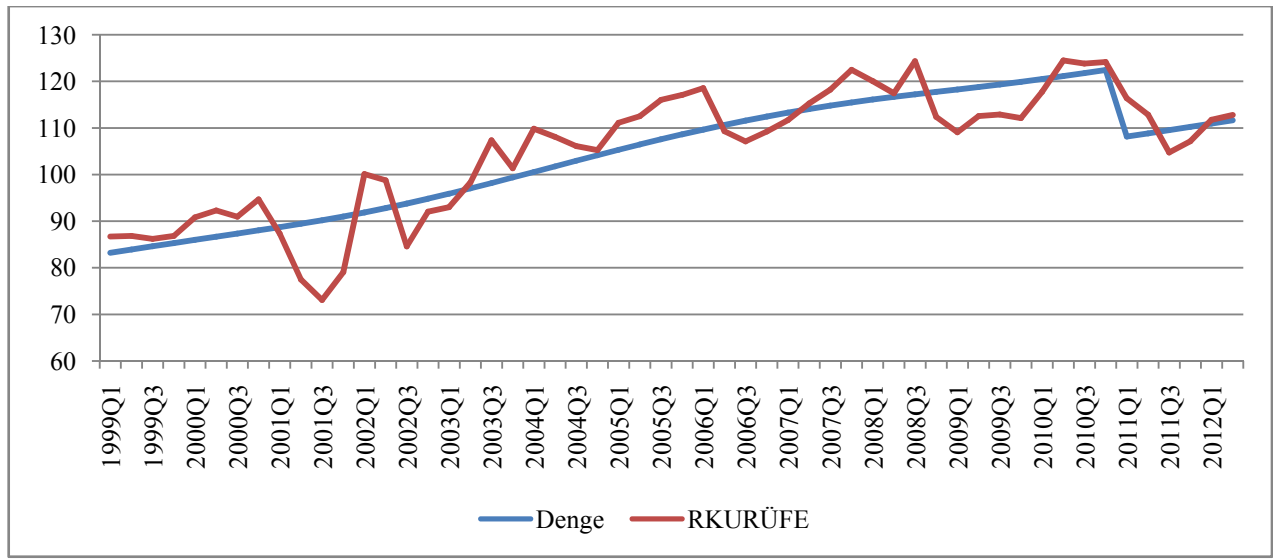

Şekil 11: Reel Kurun Denge Değeri ve Gerçekleşen Değerleri (ÜFE Bazı)

örneklem asimetrik yöntemi kullanılmıştır. Band Pass filtreleme tekniği, Hodrick-Prescott filtresinde olduğu gibi bir düzleştirme (smoothing) yapmamakta, trendin oynamasına daha fazla izin vermektedir.

TÜFE bazlı TL reel kur endeksinin denge değerinin bu yöntemle hesaplanmış değerleri Şekil 12'de verilmiştir.Elde edilen sonuçlar, Hodrick-Prescott filtresi kullanılarak elde edilen sonuçlarla büyük ölçüde örtüşmektedir. Bu yönteme göre de kriz dönemlerinde denge değerinden sapmaların arttığı ve son dönemde, Türkiye'nin reel kur endeksinin denge reel kuruna yakınsadığı söylenebilir. Merkez Bankasının son dönem politikalarının etkisi de yine bariz bir şekilde gözlemlenmektedir.

\section{SONUÇ}

Ülkelerin göreli fiyat rekabeti güçlerini yansıtan reel kur, makroekonomik dengeler açısından önemli, izlenmesi gereken bir değişkendir.Reel kurun denge değerinden uzaklaşması, diğer makroekonomik dengeler üzerinde de bozucu etkilerde bulunacaktır. Bu sebeple politika yapıcıların reel kurun denge değerinden ne kadar uzaklaştığını ve reel kurun seviyesini etkileyen değişkenlerin neler olduğunu bilmesi önemlidir.

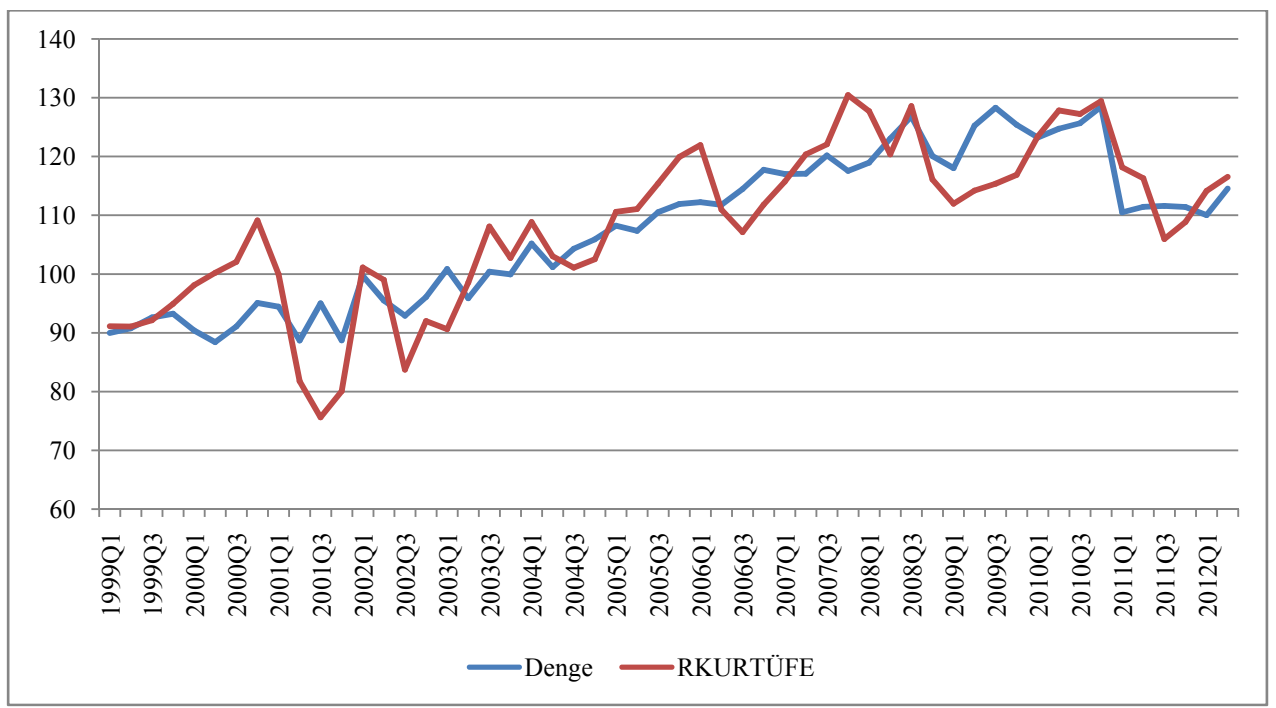

Şekil 12: Reel Efektif Döviz Kuru (TÜFE Bazlı) ve Trendi (Band-Pass Filtreleme Yöntemiyle) 
Bu çalışmada TL reel kurunun denge değerine dair çeşitli analizler yapılmış ve TL reel kurunun değeri bağımlı değişken olmak üzere FMOLS ve VEC yöntemleriyle regresyonlar yapılmıştır. Analiz sonuçlarına göre GSYH ve dış ticaret hacminin artışı reel kuru değerlenme yönünde etkilemektedir. OECD ülkelerinin Türkiye ile göreli birim iş gücü maliyetlerinin artışı reel kur üzerinde negatif anlamlı etkide bulunmaktadır; bir başka deyişle, bu ülkelerin maliyet artışı Türkiye'ye rekabet gücü artışı olarak yansımaktadır. Türkiye'ye yurt dışından sermaye akımlarının artması da TL'ye talebi artırarak reel kurda değerlenmeye yol açmaktadır. Reel kurun denge değerinden sapmaları oldukça hızlı bir şekilde trende dönüşle sonuçlanmaktadır. Merkez Bankasının 2010 Aralık ayından bu yana uyguladığı yeni para politikasının hızla etkili olmaya başladığı ve TL'nin değer kaybettiği görülmektedir.

Analiz sonuçları reel kurun denge değerinin 1999'dan bu yana yükselen bir trend izlediğini göstermektedir. Bir başka deyiş̧le, TL reel kurunun 2010 yılına kadar gösterdiği aşırı değerlenme süreci, büyük ölçüde, milli gelirin artması, dış ticaret hacmindeki artışlar, OECD ülkelerinin göreli iş gücü maliyetlerindeki düşüş gibi ekonomik temellerden kaynaklanmıştır. Söz konusu etkenler TL reel kurunun denge değerini artırmıştır. Reel kurun denge değerinden sapmalarının etkisi ise kriz dönemleri dışında genellikle önemli boyutlara ulaşmamaktadır.
TCMB'nin 2010 Aralık ayından itibaren uygulamaya koyduğu yeni para politikası ise bu tarihten sonra kurun denge değerinin düşmesinde etkili olmuştur.

Diğer taraftan, politika önerileri açısından konunun tartışııması gereken bir çok boyutu bulunmaktadır. Ekonomi literatüründe, reel kurun spekülatif olmayan, denge değeri değişimlerine politika müdahalesi yapılmaması yönünde görüşler bulunmaktadır ((Edwards (1988), Hussain (2009), Alper ve Sağlam (2000)). Türkiye örneğinde reel kurun değerlenmesinin kriz dönemleri dışında dengeden göreli olarak küçük sapmalar içermesi, ekonominin gelişim sürecinde ekonomik dinamiklerle oluşmuş, literatüre uygun, beklenen ve yaşanması ekonomik dinamikler içinde normal bir denge değerlenmesi olduğunu düşündürebilir. Ancak, yine de bu durumun üretim yapısına zarar verdiği gözlemlenmiştir. Türkiye'nin 2003 yılından 2010 yılına kadar süren reel değerlenme sürecinin ithalatı artırarak yerli üretime ve istihdama zarar verdiğini gösteren çalışmalar bulunmaktadır (Bayar, Güloğlu, Tokpunar, 2011). Bu durum, literatürdeki kanaatin sorgulanması gerektiğini göstermektedir. Nitekim Türkiye Cumhuriyet Merkez Bankasının yeni para politikası çerçevesinde yaptığı müdahalenin denge değeri üzerinde etkili olduğu, aşırı değerlenme sürecini tersine çevirmede başarılı olduğu görülmektedir. 


\section{SON NOTLAR}

${ }^{1}$ Yazarlar Sn. Doç. Dr. Bülent GÜLOĞLU'na ve Sn. Damla HACIİBRAHIMOĞLU'na katkılarından dolayı teşekkür ederler.

${ }^{2}$ Berg ve Mio (2010) makalesinin IMF çalışma kağıdı olarak yayımlanmış olması dikkat çekicidir.

${ }^{3}$ Elliot, Rothenberg-Stock ve Ng-Perron testlerinden en az birine göre I(1) olan değişkenler birinci derece bütüleşik olarak kabul edilmiş ve kullanılmışıı
${ }^{4}$ Sabit TL cinsinden GSYH serisi I(1) olmadığından ve dolar cinsinden GSYH serisi I(1) olduğundan dolar cinsinden seri tercih edilmiştir

${ }^{5}$ Denklem sonuçları yazarlardan alınabilir.

\section{KAYNAKLAR}

Achy, L. ve Sekkat, K. (2003) "The European Single Currency and MENA's Exports to Europe" Review of Development Economics, 7(4):563-582.

Ahlers, T.O. ve Hinkle, L.L. (1999) "Estimating the Equilibrium Real Exchange Rate Empirically: Operational Approaches" Hinkle et al.(eds.) Exchange Rate Misalignment: Concepts and Measurement for Developing Countries, Oxford University Press \& World Bank.

Algieri, B. (2011) "Determinants of the Real Effective Exchange Rate in the Russian Federation" The Journal of International Trade and Economic Development:An International and Comparative Review, 1-25.

Alper, C.E. ve Sağlam, İ. (2000) "The Equilibrium Real Exchange Rate: Evidence from Turkey" Topics in Middle Eastern and North African Economies, 2(1):1-15.

Aruman, S. ve Mardi, D. (2003) "A Perspective on Modelling the Australian Real Trade Weighted Index since the Float" Australian Economic Papers, 42:56-76.

Atasoy, D. ve Saxena, S. (2006)"Misaligned? Overvalued? The Untold Story of the Turkish Lira" Emerging Markets Finance and Trade, 42(3):29-45.

Balassa, B. (1964) "The Purchasing Power Parity Doctrine:A Reappraisal" Journal of Political Economy, 72:584-596.

Bayar, G., Güloğlu, B. ve Tokpunar, S. (2011) "Sanayi Sektörü İstihdamının Temel Belirleyicileri ve Dış Ticaret: Türkiye Örneği” Ekonomik Yaklaşım Kongreler Dizisi-VII, Kongre sunumu.

Bayoumi, T., Faruqee, H. ve Lee, J. (2005) "A Fair Exchange? Theory and Practice of Calculating Equilibrium Exchange Rates" International Monetary FundWorking Paper Series, No:05/229.

Berg, A. ve Miao, Y. (2010) “ The Real Exchange Rate and Growth Revisited: The Washington Consensus Strikes Back?'International Monetary Fund Working Paper Series No:10/58.
Burkart, O. ve Coudert, V. (2002) "Leading Indicators of Currency Crises for Emerging Countries" Emerging Markets Review, 3:107-33.

Bussière, M. ve Fratzscher, M.(2006) "Towards a New EarlyWarning System of FinancialCrises" Journal of International Money and Finance, 25:953-73.

Caner, M. ve Kilian, L.(2001) "Size Distortions of Tests of the Null Hypothesis of Stationarity: Evidence and Implications for the PPP Debate" Journal of International Money and Finance, 20:639-657.

Carrera, J. ve Restout, R. (2008) "Long Run Determinants of Real Exchange Rates in Latin America" GATE Groupe d'Analyse et de Théorie Économique, WP 08-11.

Christiano, L.J. ve Fitzgerald, T.J. (2003) "The Band Pass Filter" International Economic Review, 44(2):435465.

Chowdhury, K. (2011) “ Dynamics, Structural Breaks and the Determinants of the Real Exchange Rate of Australia" University of Wollongong Economics Working Paper Series No:11-11,

Cline, W.R. ve Williamson, J. (2011) "Estimates of Fundamental Equilibrium Exchange Rates" Peterson Institute of International Economics Policy Brief, No:PB11-5.

Cottani, J.A., Cavallo, D.F. ve Shahbaz, M.K. (1990) "Real Exchange Rate Behavior and Economic Performance in LDCs" Economic Development and Cultural Change, 39(1):61-72.

Coudert, V. ve Couharde, C. (2007) "Real Equilibrium Exchange Rate in China: Is theRenminbi Undervalued?” Journal of Asian Economics, 18:568-94.

Coudert, V. ve Couharde, C. (2009) "Currency Misalignments and Exchange Rate Regimes in Emerging and Developing Countries" Review of International Economics, 17(1):121-136. 
De Jong, D.N., Nankervis, J.C., Savin, N.E. ve Whiteman, C.H. (1992)“The Power Problems of Unit Root Test in Time Series With Autoregressive Errors" Journal of Econometrics, 53(1-3):323-343.

Dinçer, N. ve Kandil, M. (2011)"The Effects of Exchange Rate Fluctuations on Exports: A Sectoral Analysis for Turkey" The Journal of International Trade \& Economic Development: An International and Comparative Review, 20(6):809-837.

Doroodian, K., Jung, C. ve Yücel, A. (2002)"Estimating the Equilibrium Real Exchange Rate: The Case of Turkey" Applied Economics, 14:1807-1812.

Easterly, W. (2005) "National Policies and Economic Growth" Philippe et al.(eds.)Handbook of Economic Growth, Elsevier.

Edwards, S. (1988) "Commercial Policy, Terms of Trade and the Equilibrium Real Exchange Rate" Journal of International Economic Integration, 3(1):1-31.

Edwards, S. (2001) "Exchange Rate Regimes, Capital Flows and Crisis Prevention" National Bureau of Economic Research Working Paper, No:8529.

Elhendawy, E.Ö. (2012) "Real Exchange Rate Misalignment in Saudi Arabia" International Journal of Economics and Finance, 4(12):98-104.

Elliot, G., Rothenberg, T.J. ve Stock, J.H. (1996) "Efficient Tests for an Autoregressive Unit Root" Econometrica, 64:813-836.

Ersoy, E. (2010) "Investigation of Long-Run Real Exchange Rates: The Case of Turkey" Sosyal Bilimler Dergisi, 2:14-29.

Feyzioglu, T. (1997) "Estimating the Equilibrium Real Exchange Rate: An application to Finland" International Monetary Fund Working Paper Series, No:97/109.

Fischer, S. (2001) "Exchange Rate Regimes: Is the Bipolar View Correct?" Journal of Economic Perspectives, 15:3-24.

Ghura, D. ve Grennes, T. (1993) "The Real Exchange Rate and Macroeconomic Performance in Sub-Saharan Africa" Journal of Development Economics, 42(1):155-174.

Güloğlu, B. (2012) "Tam Değiştirilmiş EKK (Fully Modified OLS)” Ders Notu.

Hodrick, R.J. ve Prescott, E.C. (1997) "Postwar U.S. Busines Cycles: An Empirical Investigation" Journal of Money, Credit and Banking, 29(1):1-16.

Hussain, S. (2009) "Misallignmnet of Real Exchange Rate with its Equilibrium Path: Case of Pakistan"SBP Research Bulletin, 5(2):1-14.
Joyce, P.J. ve Kamas, L. (2003) "Real and Nominal Determinants of Real Exchange Rates in Latin America: Short Run Dynamics and Long Run Equilibrium" The Journal of Development Studies, 39(6):155-182.

Isard, P. (2007) "Equilibrium Exchange Rates: Assessment Methodologies" IMF Working Paper Series, No:07/296.

Kaminsky, G.L. ve Reinhart, C.M. (1999) "The Twin Crises : The Causes of Banking and Balance of Payments Problems, The American Economic Review, 89(3):473500.

Kaminsky, G., Lizondo, S. ve Reinhart, M.C. (1998) "Leading Indicators of Currency Crises" IMF Staff Papers, 45(1):1-48.

Kibritçioğlu, A. (2004) "An Analysis of Early Warning Signals of Currency Crises in Turkey 19862004" Viyana Seminer Sunuşu.

Kibritçioğlu, A. ve Kibritçioğlu, B. (2004) “Türkiye'de Uzun-Dönem Reel Döviz Kuru Dengesizliği, 1987-2003” Hazine Müsteşarlı̆̆g Araștırma ve İnceleme Dizisi, No:38.

Kumar, S. (2010) "Determinants of Real Exchange Rate in India: An ARDL Approach" Reserve Bank of India Occasional Papers, 31(1):33-64.

Lipschitz, L. ve MacDonald, D. (1992) "Real Exchange Rates and Competitiveness: A Clarification of Concepts and Some Measurement for Europe" EmpiricaAustrian Economic Papers, 19:37-69.

MacDonald, R. ve Ricci, L. (2003)"Estimation of the Equilibrium Real Exchange Rate for South Africa" IMF Working Paper Series, No:03/44.

Ng, S. ve Perron, P. (2001) "Lag Length Selection and the Construction of Unit Root Tests with Good Size and Power" Econometrica, 69:1519-1554.

Özatay, F. (2000) "The 1994 Currency Crises in Turkey" The Journal of Policy Reform, 3(4):327-352.

Özlale, Ü. ve Yeldan, E. (2002)“Measuring Exchange Rate Misalignment" ERF Working Paper Series, No:0206.

Özkan, G. (2005) "Currency and Financial Crises in Turkey 2000-2001:Bad Fundamentals or Bad Luck?"World Economy, 28(4):541-572.

Phillips, P.C.B ve Hansen, G. (1990) "Statistical Inference in Instrumental Variables Regression with I(1) Processes" Review of Economic Studies, 57:99-125.

Rodrik, D. (2008) "The Real Exchange Rate and Economic Growth" Brookings Papers on Economic Activity, 2:365-412. 
Rusek, A. (2012) "The Eurozone's Equilibrium Real Exchange Rates" Modern Economy, 3:534-541.

Samuelson, P. (1964) "Theoretical Notes and Trade Problems" Review of Economics and Statistics, 46:145-54.

Saygılı, H., Saygılı, M. ve Yılmaz, G. (2010) “Türkiye için Yeni Reel Efektif Döviz Kuru Endeksleri” Türkiye Cumhuriyet Merkez Bankası, Çalışma Tebliği No:10/12.

Schnatz, B. (1998) "Macroeconomic Determinants of Currency Turbulences in EmergingMarkets, Economic Research Group of the Deutsche Bundesbank, Discussion Paper, No:3/98.

Schwert, W. (1989) "Test for Unit Roots: A Monte Carlo Investigation" Journal of Business and Economic Statistics, 7:147-159.
Williamson, J. (1990) "What Washington Means by Policy Reform" John, W. (eds.) "Latin American Adjustment: How Much Has Happened?” Washington, Institute for International Economics.

Williamson, J. (1994)"Estimating Equilibrium Exchange Rates" Washington DC, Institute for International Economics.

You, K. ve Sarantis, N. (2011) "Structural Breaks and the Equilibrium Chinese Yuan/US Dolar Real Exchange Rate: A FEER Approach" Review of International Economics, 19(5):791-808. 


\section{EKLER}

\section{EK-1 : Birim Kök Testlerinin Sonuçları}

Tablo E1: Elliott-Rothenberg-Stock Point Optimal Birim Kök Testi Sonuçları

\begin{tabular}{|c|c|c|}
\hline Değişken & P-İstatistikleri & \multirow{7}{*}{$\begin{array}{l}\text { Not: Elliott-Rothenberg-Stock kritik test değerleri: } \\
\% 1 \text { seviyesinde } 1,8828, \% 5 \text { seviyesinde } \% 2,9924^{\prime} \text { tür. } \\
*^{*},{ }^{* *} \text { işaretleri sırasıyla } \% 5 \text { ve } \% 1 \text { düzeyinde an- } \\
\text { lamlılığı ifade etmektedir. Gecikmelerin uzunlukları } \\
\text { Schwarz krtiterine göre seçilmiştir ve maksimum ge- } \\
\text { cikme uzunluğu } 10^{\prime} \text { 'dur. }\end{array}$} \\
\hline Dolar GSYH (logaritmik) & 64.01654 & \\
\hline D(Dolar GSYH logaritmik) & $0.652507^{* * * *}$ & \\
\hline Dış Ticaret Hacmi/GSYH (logaritmik) & 86.95723 & \\
\hline D(Dış Ticaret Hacmi GSYH logaritmik) & $0.264294^{* * *}$ & \\
\hline Büyüme & $1.443438^{* * *}$ & \\
\hline D(Büyüme) & $1.286938^{* * *}$ & \\
\hline
\end{tabular}

Hizmetler Dahil Dış Ticaret Hacmi/GSYH $1.286938^{* * *}$

\begin{tabular}{ll}
\hline D(Hizmetler Dahil Dış Ticaret Hacmi/GSYH) & 24.06968 \\
\hline
\end{tabular}

\begin{tabular}{|l|r}
\hline TCMB Döviz Rezervi (log) & 84.81445 \\
\hline
\end{tabular}

\begin{tabular}{|l|c|}
\hline D(TCMB Döviz Rezervi) & $0.683008^{* * *}$ \\
\hline
\end{tabular}

\begin{tabular}{|l|r}
\hline Faiz Farkı & 699.3806 \\
\hline
\end{tabular}

\begin{tabular}{|l|r}
\hline D(Faiz Farkı) & 1274.88 \\
\hline Goreli Birm
\end{tabular}

\begin{tabular}{|l|c|}
\hline Göreli Birim İş Gücü Maliyeti(OECD/TR) & 3.79617 \\
\hline D(Göreli İ̧̧ Gücü Maliyeti) & $1.201734^{* * *}$ \\
\hline
\end{tabular}

\begin{tabular}{|l|r}
\hline Sermaye Girişi/GSYH & 3.02351 \\
\hline
\end{tabular}

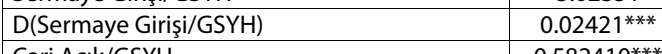

\begin{tabular}{|l|r|}
\hline Cari Açık/GSYH & $0.582410^{* * *}$ \\
\hline D(Cari Açık/GSYH) & 28.67516 \\
\hline
\end{tabular}

\begin{tabular}{|l|l}
\hline GDP Sabit Fiyatlarla & 58.29337 \\
\hline
\end{tabular}

\begin{tabular}{|l|l}
\hline D(GDP Sabit Fiyatlarla) & 7.190422 \\
\hline
\end{tabular}

\begin{tabular}{|l|r}
\hline Kamu Tüketimi & 16.85005 \\
\hline
\end{tabular}

\begin{tabular}{|r|r}
\hline $\mathrm{D}$ (Kamu Tüketimi) & 2.880548 \\
\hline
\end{tabular}

\begin{tabular}{|l|l}
\hline Kamu Yatırımı & 16.22551
\end{tabular}

\begin{tabular}{|l|r|}
\hline D(Kamu Yatırımı) & 32.42274 \\
\hline
\end{tabular}

\begin{tabular}{|l|l|}
\hline Kısa Vadeli Banka Kredileri & $1.554685^{* * *}$ \\
\hline
\end{tabular}

\begin{tabular}{|l|l|}
\hline D(Kısa Vadeli Banka Kredileri) & $2.019547^{* *}$ \\
\hline Kur Standar
\end{tabular}

\begin{tabular}{|l|l|}
\hline Kur Standart Sapma & $2.244681^{* * * *}$ \\
\hline
\end{tabular}

\begin{tabular}{|l|l|}
\hline $\mathrm{D}$ (Kur Standart Sapma ) & $1.248501^{* * *}$ \\
\hline
\end{tabular}

\begin{tabular}{|l|r}
\hline Reel Faiz Gerçekleşme & 95.48101 \\
\hline
\end{tabular}

\begin{tabular}{|l|r}
\hline D(Reel Faiz Gerçekleşme) & 3.323391 \\
\hline
\end{tabular}

\begin{tabular}{|l|l}
\hline Toplam Yatırım/GSYH & $2.144186^{* *}$
\end{tabular}

\begin{tabular}{|r|r}
\hline D(Toplam Yatırım/GSYH) & 10.91654
\end{tabular}

\begin{tabular}{|l|l}
\hline Güven Endeksi & 3.015243
\end{tabular}

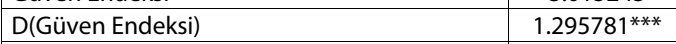

\begin{tabular}{|l|r}
\hline Verimlilik & 265.9751 \\
\hline
\end{tabular}

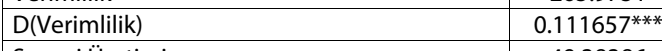

\begin{tabular}{|l|r}
\hline Sanayi Üretimi & 49.38386
\end{tabular}

\begin{tabular}{|l|l|}
\hline $\mathrm{D}$ (Sanayi Üretimi) & 3.010986 \\
\hline
\end{tabular}

\begin{tabular}{|l|r}
\hline Ticaret Haddi & 53.37344
\end{tabular}

\begin{tabular}{|l|c|}
\hline $\mathrm{D}$ (Ticaret Haddi) & $2.826933^{* *}$ \\
\hline $\mathrm{M} 2$ & 3566.379 \\
\hline
\end{tabular}

\begin{tabular}{|l|r|}
\hline M2 & 3566.379 \\
\hline
\end{tabular}

\begin{tabular}{|l|r|}
\hline $\mathrm{D}(\mathrm{M} 2)$ & 3566.379 \\
\hline
\end{tabular}

\begin{tabular}{|l|r}
\hline TCMB Toplam Rezerv (log) & 97.39305
\end{tabular}

\begin{tabular}{|l|c|}
\hline D(TCMB Toplam Rezerv) & $0.701771^{* * *}$ \\
\hline
\end{tabular}

\begin{tabular}{|l|r}
\hline Kamu Harcamaları & 321.5792 \\
\hline
\end{tabular}

\begin{tabular}{|l|l|}
\hline D(Kamu Harcamaları) & 321.5792 \\
\hline
\end{tabular}

\begin{tabular}{|l|r}
\hline İhracat Birim Fiyat Endeksi & 29.21445 \\
\hline
\end{tabular}

\begin{tabular}{|l|l|}
\hline D(Ihracat Birim Fiyat Endeksi) & $2.486731^{* * *}$ \\
\hline
\end{tabular}

\begin{tabular}{|l|l}
\hline İthalat Birim Fiyat Endeksi & 40.26181
\end{tabular}

\begin{tabular}{|l|l|}
\hline D(Ithalat Birim Fiyat Endeksi) & $0.601271^{* * *}$ \\
\hline
\end{tabular}

\begin{tabular}{|l|r}
\hline İhracat Miktar Endeksi & 26.12071 \\
\hline
\end{tabular}

\begin{tabular}{|l|l|}
\hline D(Ihracat Miktar Endeksi) & $0.499224^{* * * *}$ \\
\hline
\end{tabular}

\begin{tabular}{|l|r|}
\hline İthalat Miktar Endeksi & 26.50015 \\
\hline
\end{tabular}

\begin{tabular}{|l|l|}
\hline D(İthalat Miktar Endeksi) & $0.036558^{* * * *}$ \\
\hline
\end{tabular}

\begin{tabular}{|l|r}
\hline Ticaret Ortakları GDP & 7.491892
\end{tabular}

\begin{tabular}{|l|l}
\hline D(Ticaret Ortakları GDP) & 3.527713 \\
\hline
\end{tabular}

\begin{tabular}{|l|l}
\hline Doğrudan Yabancı Yatırım & 4.100521
\end{tabular}

\begin{tabular}{|l|l|}
\hline D(Doğrudan Yabancı Yatııı) & $1.43172^{* * *}$ \\
\hline
\end{tabular}

\begin{tabular}{|r|r}
\hline TCMB Altın Rezervi & 183.45
\end{tabular}

\begin{tabular}{|l|l|}
\hline D(TCMB Altın Rezervi) & 2.659673**** \\
\hline
\end{tabular} 
Tablo E1: Ng-Perron Birim Kök Testi Sonuçları

\begin{tabular}{|c|c|c|c|c|}
\hline Değişken & $\mathrm{MZa}$ & $\mathrm{MZt}$ & MSB & MPT \\
\hline Dolar GSYH (logaritmik) & -0.1568 & -0.09674 & 0.61698 & 24.7004 \\
\hline D(Dolar GSYH logaritmik) & -2.78272 & -1.17698 & 0.42296 & 8.79585 \\
\hline Dış Ticaret Hacmi/GSYH (logaritmik) & 1.22364 & 0.97274 & 0.79496 & 48.4555 \\
\hline D(Dış Ticaret Hacmi GSYH) & 0.01025 & 0.01469 & 1.43248 & 107.702 \\
\hline Hizmetler Dahil Dış Ticaret Hacmi/GSYH & -0.79003 & -0.39413 & 0.49888 & 16.3622 \\
\hline D(Hizmetler Dahil Dış Ticaret & 0.14835 & 0.12702 & 0.85624 & 44.2832 \\
\hline TCMB Döviz Rezervleri (Log) & 0.20539 & 0.14120 & 0.68747 & 31.3597 \\
\hline D(TCMB Döviz Rezervleri) & $-34.6920^{* * *}$ & $-4.16322^{* * *}$ & $0.12001 * * *$ & $0.71104 * * *$ \\
\hline Faiz Farkı & -2.48986 & -0.9867 & 0.39629 & 9.19213 \\
\hline $\mathrm{D}$ (Faiz Farkı) & 0.00192 & 0.01049 & 5.4674 & 1472.38 \\
\hline Göreli Birim İş Gücü Maliyeti (OECD/TR) & -1.55915 & -0.86632 & 0.55564 & 15.3839 \\
\hline D(Göreli İş Gücü Maliyeti) & $-23.8869 * * *$ & $-3.44354^{* * *}$ & $0.14416^{* * *}$ & $1.06746^{* * *}$ \\
\hline Sermaye Girişi/GSYH & $-15.3502^{* * *}$ & $-2.63169 * * *$ & $0.17144^{* * *}$ & $2.11077^{* *}$ \\
\hline D(Sermaye Girişi/GSYH) & $-41.6233^{* * *}$ & $-4.52443^{* * *}$ & $0.1087^{* * *}$ & $0.69151^{* * *}$ \\
\hline Cari Açık/GSYH & $-58.1777^{* * *}$ & $-5.36142^{* * *}$ & $0.09216^{* * *}$ & $0.49737^{* * *}$ \\
\hline $\mathrm{D}($ Cari Açık/GSYH) & -1.33499 & -0.81551 & 0.61087 & 18.3101 \\
\hline GDP Sabit Fiyatlarla & -0.08316 & -0.04664 & 0.56087 & 21.923 \\
\hline D(GDP Sabit Fiyatlarla) & -0.1349 & -0.24148 & 1.79006 & 157.942 \\
\hline Kamu Tüketimi & 1.0895 & 2.57679 & 2.36512 & 364.675 \\
\hline D(Kamu Tüketimi) & 0.01973 & 0.08106 & 4.10959 & 838.987 \\
\hline Kamu Yatırımı & -1.36467 & -0.77441 & 0.56747 & 16.6107 \\
\hline $\mathrm{D}$ (Kamu Yatırımı) & -0.31825 & -0.26566 & 0.83476 & 37.9645 \\
\hline Kısa Vadeli Banka Kredileri & $-17.4456^{* * *}$ & $-2.90792^{* * *}$ & $0.16668^{* * *}$ & $1.57148^{* * *}$ \\
\hline $\mathrm{D}($ Kısa Vadeli Banka Kredileri) & $-25.317^{* * *}$ & $-3.53233^{* * *}$ & $0.13952^{* * *}$ & $1.05213^{* * *}$ \\
\hline Kur Standart Sapma & $-24.9067^{* * *}$ & $-3.52888^{* * *}$ & $0.14168^{* * *}$ & $0.98383^{* * *}$ \\
\hline $\mathrm{D}$ (Kur Standart Sapma ) & $-18.713^{* * *}$ & $-3.05362^{* * *}$ & $0.16318^{* * *}$ & $1.32821 * * *$ \\
\hline Reel Faiz Gerçekleşme & -0.8515 & -0.48303 & 0.56728 & 18.8725 \\
\hline D(Reel Faiz Gerçekleşme) & -0.16954 & -0.27083 & 1.59744 & 125.964 \\
\hline Toplam Yatırım/GSYH & $-19.4728^{* * *}$ & $-3.07764^{* * *}$ & $0.15805^{* * *}$ & $1.41057^{* * *}$ \\
\hline D(Toplam Yatırım/GSYH) & -0.37694 & -0.40057 & 1.06269 & 56.357 \\
\hline Güven Endeksi & $-10.1464^{* *}$ & $-2.22771^{* *}$ & $0.21956^{* *}$ & $2.51165^{* *}$ \\
\hline D(Güven Endeksi) & $-25.4866^{* * *}$ & $-3.56572^{* * *}$ & $0.13991^{* * *}$ & $0.9747^{* * *}$ \\
\hline Verimlilik & 0.22763 & 0.1508 & 0.66247 & 29.7415 \\
\hline $\mathrm{D}$ (Verimlilik) & -0.91168 & -0.53843 & 0.59059 & 19.5892 \\
\hline Sanayi Üretimi & 0.67618 & 0.40723 & 0.60225 & 28.0091 \\
\hline $\mathrm{D}$ (Sanayi Üretimi) & -8.06367 & $-1.98288^{* *}$ & 0.2459 & $3.13326^{* *}$ \\
\hline Ticaret Haddi & 0.21388 & 0.11831 & 0.55317 & 22.7605 \\
\hline $\mathrm{D}$ (Ticaret Haddi) & $-12.2388^{* *}$ & $-2.46429^{* *}$ & $0.20135^{* *}$ & $2.03891^{* *}$ \\
\hline M2 & 0.93252 & 0.95946 & 1.02889 & 72.2995 \\
\hline $\mathrm{D}(\mathrm{M} 2)$ & -5.60107 & -1.51798 & 0.27102 & 4.81563 \\
\hline TCMB Toplam Rezerv (log) & 0.51628 & 0.37034 & 0.71733 & 35.7308 \\
\hline D(TCMB Toplam Rezerv) & $-33.7684^{* * *}$ & $-4.10559^{* * *}$ & $0.12158^{* * *}$ & $0.73583^{* * *}$ \\
\hline Kamu Harcamaları & 0.5918 & 0.73805 & 1.24714 & 95.7237 \\
\hline $\mathrm{D}$ (Kamu Harcamaları) & -0.19597 & -0.22496 & 1.14797 & 67.893 \\
\hline İhracat Birim Fiyat Endeksi & -0.30888 & -0.17526 & 0.56741 & 21.2754 \\
\hline $\mathrm{D}$ (Ihracat Birim Fiyat Endeksi) & $-45.8285^{* * *}$ & $-4.78675^{* * *}$ & $0.10445^{* * *}$ & $0.53496^{* * *}$ \\
\hline İthalat Birim Fiyat Endeksi & 0.25831 & 0.15633 & 0.60517 & 26.1099 \\
\hline D(Ithalat Birim Fiyat Endeksi) & $-51.6392^{* * *}$ & $-5.06708^{* * *}$ & $0.09812^{* * *}$ & $0.51015^{* * *}$ \\
\hline İhracat Miktar Endeksi & -0.4506 & -0.24401 & 0.54151 & 19.4196 \\
\hline D(Ihracat Miktar Endeksi) & $-44.895^{* * *}$ & $-4.73773^{* * *}$ & $0.10553^{* * *}$ & $0.54612^{* * *}$ \\
\hline İthalat Miktar Endeksi & -0.90341 & -0.41368 & 0.45791 & 14.5389 \\
\hline D(İthalat Miktar Endeksi) & $-28.4102^{* * *}$ & $-3.76146^{* * *}$ & $0.1324^{* * *}$ & $0.88625^{* * *}$ \\
\hline Ticaret Ortakları GDP & -3.21201 & -1.24334 & 0.38709 & 7.59918 \\
\hline $\mathrm{D}$ (Ticaret Ortakları GDP)* & $-23.1231^{* * *}$ & $-2.91602^{* * *}$ & $0.12611^{* * *}$ & $2.59537^{* *}$ \\
\hline Doğrudan Yabancı Yatırım & -6.49569 & -1.78649 & 0.27503 & 3.8254 \\
\hline D(Doğrudan Yabancı Yatırım) & $-17.5214^{* * *}$ & $-2.95809^{* * *}$ & $0.16883^{* * *}$ & $1.40481^{* * *}$ \\
\hline TCMB Altın Rezervi (log) & 3.78072 & 4.07153 & 1.07692 & 123.923 \\
\hline D(TCMB Altın Rezervi) & $-24.5041^{* * *}$ & $-3.46224^{* * *}$ & $0.14129^{* * *}$ & $1.12667^{* * *}$ \\
\hline
\end{tabular}

Not: Ng-Perron asimptotik test değerleri (trendsiz): $\% 1$ seviyesinde: $\mathrm{MZa}=-13,8$ $M Z t=-2,58, \quad M S B=0,174$, MPT $=1,78 ; \quad \% 5$ seviyesinde: $\quad M Z a=-8,1, \quad M Z t=-1,98$, $M S B=0,233, M P T=3,17$.

**, *** işaretleri sırasıyla $\% 5$ ve $\% 1$ düzeyinde anlamlılığı ifade etmektedir. Gecikmelerin uzunlukları Schwarz krtiterine göre seçilmiştir ve maksimum gecikme uzunluğu 10'dur. 
EK-2: İçsellik LR Testi (VEC Denklemi)

Tablo E2: içsellik LR Testi Sonuçları

\begin{tabular}{|c|c|c|c|c|}
\hline Değişken & IndolarGSYH & SermayeGiriş & GoreliOECDTR & InDışTicGSYH \\
\hline Ki-Kare & 0.060598 & 1.59502 & 2.524138 & 12.63688 \\
\hline Olasılık & 0.805553 & 0.20661 & 0.112116 & 0.000378 \\
\hline
\end{tabular}

EK-3: Kalıntı Otokorelasyon Testi (VEC Denklemi)

Tablo E3:Kalıntı Otokorelasyonu LM Testi Boş hipotez: h gecikmesinde otokorelasyon yoktur.

Gözlem Sayısı: 48

\begin{tabular}{|c|c|c|}
\hline Gecikme Uzunluğu & LM-İstatistiği & Olasılık \\
\hline 1 & 1.249304 & 0.8699 \\
\hline 2 & 1.42813 & 0.8393 \\
\hline 3 & 1.788376 & 0.7746 \\
\hline 4 & 2.817674 & 0.5888 \\
\hline 5 & 3.24959 & 0.517 \\
\hline 6 & 17.00775 & 0.0019 \\
\hline 7 & 5.415985 & 0.2472 \\
\hline 8 & 0.172424 & 0.9965 \\
\hline 9 & 2.568464 & 0.6324 \\
\hline 10 & 2.952709 & 0.5658 \\
\hline 11 & 0.772138 & 0.9421 \\
\hline 12 & 4.625265 & 0.328 \\
\hline
\end{tabular}

